\title{
Flip Chip - Chip Scale Package Bonding Technology with Type 7 Solder Paste Printing
}

\author{
Type 7 솔더 페이스트 프린팅 공정을 적용한 플립칩 - 칩 스케일 패키지 접합기술 \\ Mi-Song Kim*, Won Sik Hong*, , and Myeongin Kim* \\ *Electronic Convergence Materials \& Device Research Center, Korea Electronics Technology Institute, \\ Seongnam, 13509, Korea
}

†Corresponding author: wshong@keti.re.kr

(Received July 28, 2021; Revised July 30, 2021; Accepted August 3, 2021)

\begin{abstract}
In this study, thermo-compression(TC) and vacuum reflow(VR) bonding processes of fine pitch interconnection were optimized using Type $7 \mathrm{Sn}-3.0 \mathrm{Ag}-0.5 \mathrm{Cu}$ solder paste. A chip with $\mathrm{Cu}$ pillar $\mathrm{Sn}-2.5 \mathrm{Ag}$ bumps and BT substrate with ENEPIG surface finish were used, and the thickness and the aperture ratio of the metal mask were $30 \mu \mathrm{m} / 50 \mu \mathrm{m}$ and $70 \% / 100 \%$, respectively. As a result of optimizing the printing process, a metal mask with a thickness of $30 \mu \mathrm{m}$ and an aperture ratio of $100 \%$ was selected. As a result of the TC and VR bonding processes optimization, $\mathrm{Cu}_{6} \mathrm{Sn}_{5}$ and $(\mathrm{Cu}, \mathrm{Ni})_{6} \mathrm{Sn}_{5} \mathrm{IMC}$ layers were formed on the top and bottom of the solder joint, respectively. In the conventional TC process sample, the thickness of the solder was measured to be $4.1 \mu \mathrm{m}$, and the IMC thickness ratio was calculated to be $40 \%$. Also, in the TC and VR process samples with solder paste, the thickness of the solder was measured to be $6.5 \mu \mathrm{m}$ and $10.3 \mu \mathrm{m}$, respectively, and the ratio of the IMC thickness was calculated to be about $32 \%$ and $43 \%$. It was expected that it would be beneficial to reliability by reducing the occurrence and propagation of cracks in the solder joint due to the effect of lowering the IMC thickness ratio as the volume of the solder becomes larger than that of the conventional TC process.
\end{abstract}

Key Words: Thermo-compression, Vacuum reflow, $\mathrm{Cu}$ pillar bump, Type 7 solder paste, ENEPIG

\section{Introduction}

The inputs and outputs (I/Os) of semiconductor packages are increasing and a high density of interconnections is being demanded as electronic products are becoming more functional and smaller. The semiconductor package interconnection technologies include wire bonding technology and flip chip bonding technology as shown in Fig. 1, which interconnects the electrodes of substrates by solder joint. The flip chip bonding technology can connect more I/Os than the wire bonding technology because it can use the front surface of the chip, and has the advantage of fast signal processing because the chip is approximately 10 times shorter than the wire length. Therefore, it is being ap- plied in various ways for interconnection of high-density packages or digital packages that require fast signal processing ${ }^{1-5)}$.

For high-density I/O packages, it is necessary to research on the reduction of the pitch of joint bump. For bump sizes of $150 \mu \mathrm{m}$ or more, the printing process of solder paste, or solder balls are applied. If the pitch of the bump decreases to $150 \mu \mathrm{m}$ or less, electrical short circuit may occur due to solder bridge; hence, solder deposition or plating method is used as shown in Fig. 1 (c). Since the height of the joint decreases as the bump becomes smaller, it becomes difficult to achieve reliability and perform underfill at pitches of $140 \mu \mathrm{m}$ or less. Therefore, the $\mathrm{Cu}$ pillar bump technology that forms a Sn-based solder cap on a Cu pillar is applied at bump pitches of $140 \mu \mathrm{m}$ or less ${ }^{1-5)}$. 


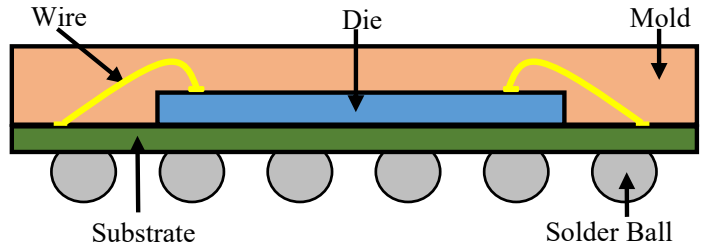

(a)

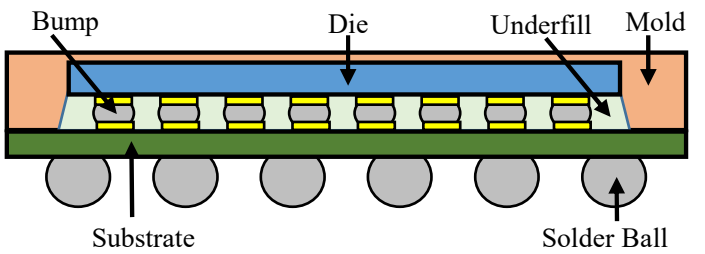

(b)

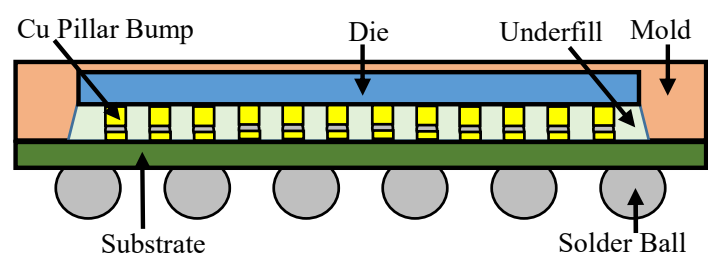

(c)

Fig. 1 Schematic structural diagram of (a) wire bonding package, (b) flip chip-chip scale package (FCCSP) and (c) fine pitch FCCSP

$\mathrm{Cu}$ electrode pad and $\mathrm{Cu}$ pillar bump are joined, $\mathrm{Cu}-$ Sn-based intermetallic compounds (IMC) are formed. The smaller the bump size, the higher the percentage of IMC in the joint and the lower its reliability becomes. To improve this problem, the Ni-layer, which plays the role of preventing diffusion on a $\mathrm{Cu}$ electrode pad with a fine pitch, is formed by plating, or a $\mathrm{Cu}$ pillar bump plated with a highly reliable ternary solder is formed. However, ternary plating has the disadvantage of low mass production capacity due to a difficulty in plating solution management. Therefore, surface treatment methods such as electroless-nickel immersion-gold (ENIG) and electroless-nickel electroless-palladium immersiongold (ENEPIG) are mainly applied to the $\mathrm{Cu}$ electrode pad. In particular, the ENEPIG technology has been reported to have excellent mechanical reliability by suppressing the formation of kirkendall voids at the ENIG joint $^{5-9)}$.

This study optimized the thermo-compression (TC) bonding process of the flip chip-chip scale package (FC-CSP) using a chip with a $\mathrm{Cu}$ pillar $\mathrm{Sn}-2.5 \mathrm{Ag}$ bump of a $150 \mu \mathrm{m}$ pitch and an ENEPIG-surface-treated bismaleimide triazine (BT) substrate. In addition, this study investigated optimization of the thermo-compression (TC) bonding process and vacuum reflow (VR) bonding process, which applied a ternary lead-free solder using a type $7 \mathrm{Sn}-3.0 \mathrm{Ag}-0.5 \mathrm{Cu}$ solder paste.

\section{Experiment Method}

\subsection{Analysis of raw and subsidiary materials}

The substrate used in this experiment was an ENEPIGsurface-treated BT substrate with a size of $15 \times 15 \mathrm{~mm}$ as shown in Fig. 2. The substrate thickness was $0.3 \mathrm{~mm}$, and the surface treatment thickness was 3-8 $\mu \mathrm{m}$ for $\mathrm{Ni}$, 0.05-0.15 $\mu \mathrm{m}$ for $\mathrm{Pd}$, and 0.05-0.15 $\mu \mathrm{m}$ for Au. Regarding the chip, a $10 \times 15 \mathrm{~mm}$ chip with $1,744 \mathrm{Cu}$ pillar/Sn-2.5Ag bumps with a diameter of $90 \mu \mathrm{m}$, a pitch of $150 \mu \mathrm{m}$, and a height of approximately $50 \mu \mathrm{m}$ was used as shown in Fig. 3. For the solder paste, the composition of Sn-3.0Ag-0.5Cu (MKE Co. Ltd., Korea) was used, and the printing processability was evaluated using type 5 and type 7. As shown in Fig. 4, the solder
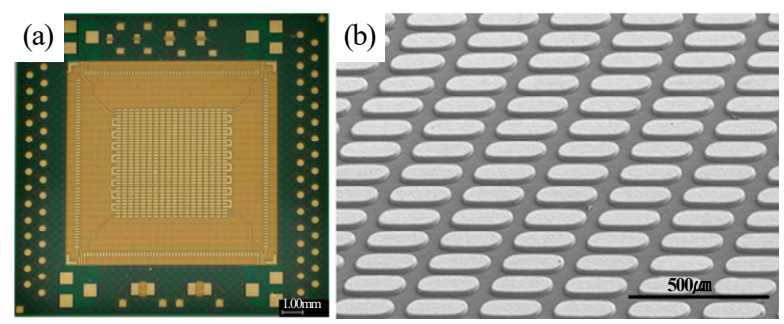

Fig. 2 Optical and SEM micrographs of BT substrate for FC-CSP, (a) top side and (b) magnified ENEPIG pad
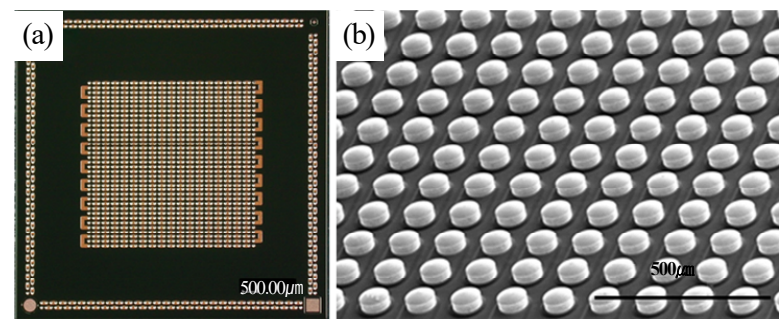

Fig. 3 Optical and SEM micrographs of Si flip chip, (a) bump side and (b) magnified $\mathrm{Cu}$ pillar bump
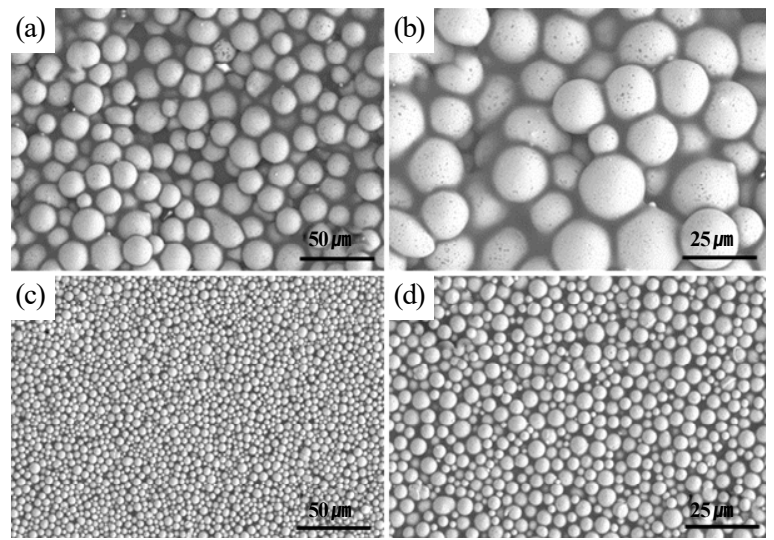

Fig. 4 SEM micrographs of solder pastes, (a,b) Type 5 and (c,d) Type 7 
ball sizes of type 5 and type 7 were $15-25 \mu \mathrm{m}$ and 2-11 $\mu \mathrm{m}$, respectively.

\subsection{Jig design and fabrication}

A printing jig that can be fine-tuned for fine pitch solder paste printing was fabricated as shown in Fig. 5. The metal mask thicknesses were $50 \mu \mathrm{m}$ and $30 \mu \mathrm{m}$, and the opening ratios were $70 \%$ and $100 \%$. The reflow bonding of the fine pitch FC-CSP chip requires a jog for aligning the bumps, and the jig was fabricated as shown in Fig. 6, in such a way that the FC-CSP chip can be fixed after printing. A jig that can fix the substrate was fabricated to suppress the generation of warpage at high temperatures due to the nature of BT substrate.

\subsection{Solder paste printing}

The optimal solder paste and metal mask that do not

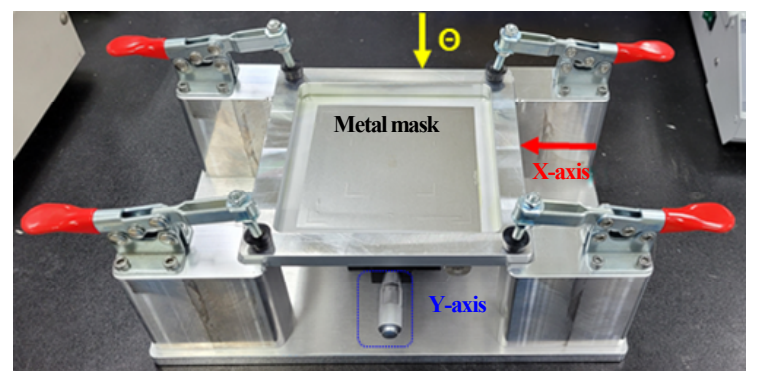

Fig. 5 Photograph of Photograph of printing jig with $\mathrm{X} / \mathrm{Y} /$ $\Theta$ axis adjustment for solder paste printing on the FC-CSP substrate cause defects such as bridge were selected by evaluating the printability of type 5 and type 7 solder pastes according to powder particle size, metal mask thickness, and opening ratio.

\subsection{Thermo-compression bonding}

The thermo-compression (TC) bonding process used the flip chip bonder (NM-SB50A, Panasonic Co. Ltd., Japan). After bonding, the chip-substrate bonding condition was determined by measuring the electrical characteristics of all bumps connected to the daisy chain after bonding. The process conditions are listed in Table 1. As shown in Table 1, bonding profiles 2-1 and 2-2, void characteristics were evaluated by fabricating fluxapplied sample and the un-applied sample. The TC bonding process of the chip with $\mathrm{Cu}$ pillar/Sn-2.5Ag bumps and the BT substrate were optimized. In addition, after the type $7 \mathrm{Sn}-3.0 \mathrm{Ag}-0.5 \mathrm{Cu}$ solder paste and bonding were printed, the microstructures of the joints were compared.

\subsection{Vacuum reflow bonding}

The vacuum reflow (VR) bonding process used the RSS-210-S (UniTemp Co. Ltd., Germany) system with the process conditions in Fig. 7. As shown in Fig. 7 (e), the bonding profile was analyzed while changing the temperature rise rate, soak time, peak temperature and time. The temperatures on the jig surface were measured as shown in Fig. 7 (c). It started in nitrogen atmosphere and the vacuum atmosphere was formed in the
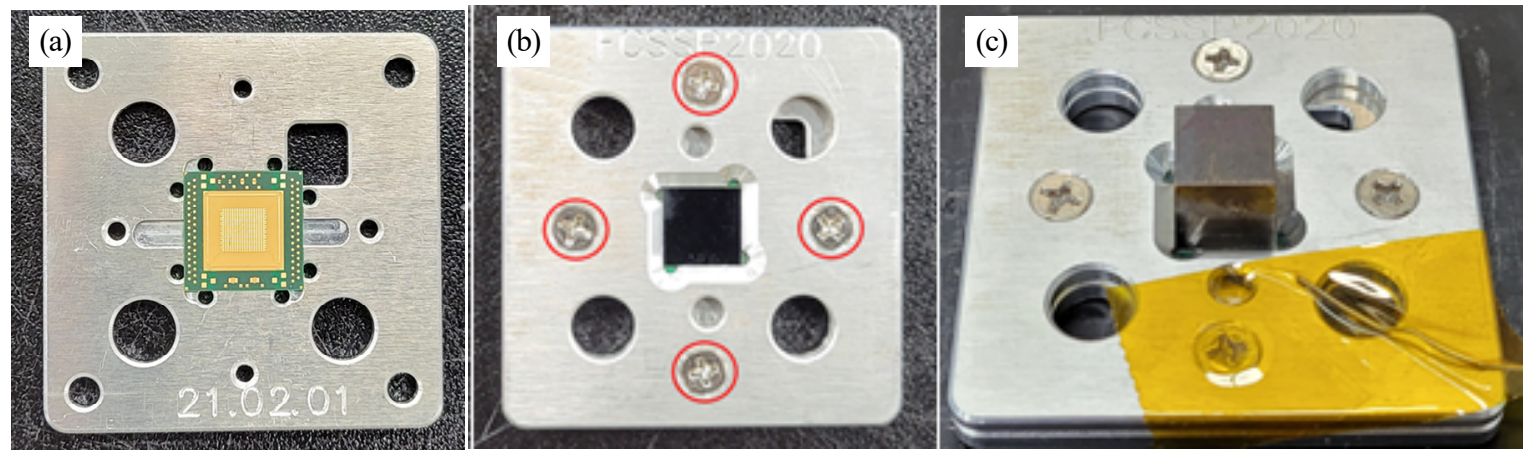

Fig. 6 Photographs of vacuum reflow bonding jig, (a) Lower jig, (b) upper jig and (c) weight compression after the jig joining

Table 1 The temperature and the pressure profile condition for thermo-compression bonding

\begin{tabular}{|c|c|c|c|c|c|}
\hline Bonding profile & Stage Temp. $\left({ }^{\circ} \mathrm{C}\right)$ & Head Temp. $\left({ }^{\circ} \mathrm{C}\right)$ & Time $(\mathrm{sec})$ & Load $(\mathrm{N})$ & Flux \\
\hline 1 & 80 & 320 & 35 & 10 & $\mathrm{x}$ \\
\hline $2-1$ & 100 & 320 & 35 & 10 & $\mathrm{o}$ \\
\hline $2-2$ & 100 & 320 & 35 & 10 & $\mathrm{x}$ \\
\hline 3 & 100 & 320 & 15 & 10 & $\mathrm{x}$ \\
\hline
\end{tabular}



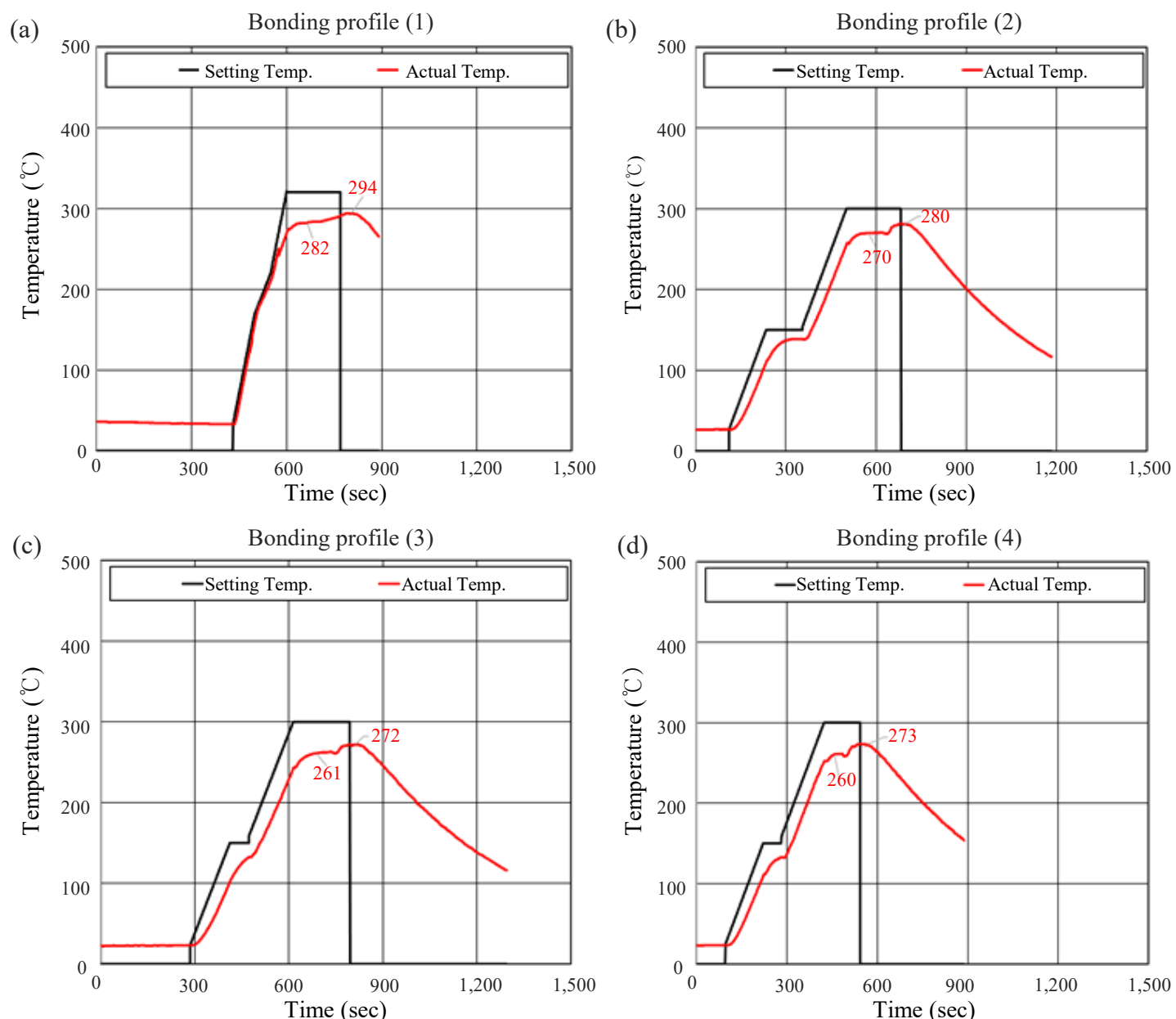

(e)

\begin{tabular}{|c|c|c|c|c|}
\hline Profile No. & $\mathbf{1}$ & $\mathbf{2}$ & $\mathbf{3}$ & $\mathbf{4}$ \\
\hline Soak zone & - & $120 \mathrm{sec}$ at $150{ }^{\circ} \mathrm{C}$ & \multicolumn{2}{|c|}{60 sec. at $150{ }^{\circ} \mathrm{C}$} \\
\hline Peak zone & $130 \mathrm{sec}$. at $320{ }^{\circ} \mathrm{C}$ & $180 \mathrm{sec}$ at $300{ }^{\circ} \mathrm{C}$ & 180 sec. at $300{ }^{\circ} \mathrm{C}$ & 120 sec. at $300{ }^{\circ} \mathrm{C}$ \\
\hline Ramp up rate & $2{ }^{\circ} \mathrm{C} / \mathrm{sec}$. & & $1{ }^{\circ} \mathrm{C} / \mathrm{sec}$. \\
\hline
\end{tabular}

Fig. 7 Bonding profiles of vacuum reflow bonding, (a-d) set and measured temperature and (e) profile condition

peak temperature range, and cooling was performed by injecting nitrogen. During the bonding process, the bonding process was performed under a load of $0.18 \mathrm{~N}$ by pressurizing with an $18 \mathrm{~g}$ weight. Samples were fabricated for the case of pressurizing the top and bottom surfaces of the jig with screws and the case of no pressurizing, and the joints were compared.

\section{Experiment Results}

\subsection{Characteristics of printing process}

The printing process results according to the solder paste type, metal mask thickness and opening ratio are shown in Fig. 8. When type 5 solder paste was printed, the solder ball did not fall out easily as shown in (a), and the printing was not done evenly when the $50 \mu \mathrm{m}$ metal mask was used. Finally, type $7 \mathrm{Sn}-3.0 \mathrm{Ag}-0.5 \mathrm{Cu}$

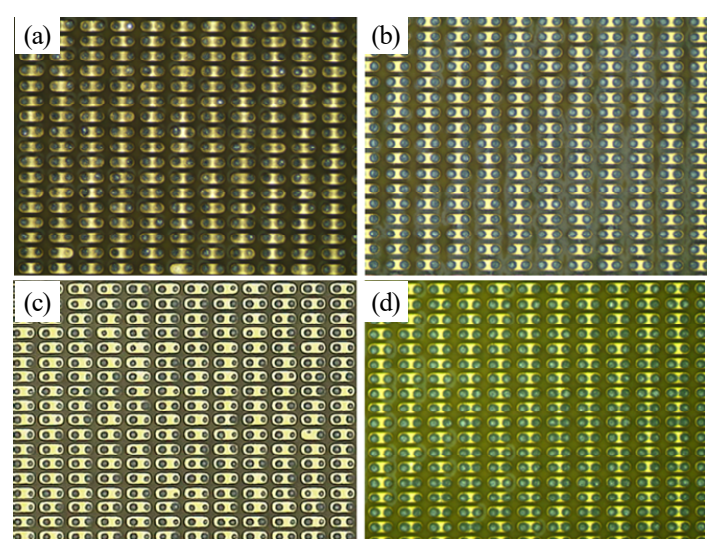

Fig. 8 Optical micrographs after solder paste printing on the pad of BT substrate, (a) Type 5 solder paste, $30 \mu \mathrm{m} / 70 \%$ metal mask, (b) Type 7 solder paste, $30 \mu \mathrm{m} / 70 \%$ metal mask, (c) Type 7 solder paste, $50 \mu \mathrm{m} / 70 \%$ metal mask and (d) Type 7 solder paste, $30 \mu \mathrm{m} / 100 \%$ metal mask 
solder paste and $30 \mu \mathrm{m}$ metal mask were selected, and they were printed with $70 \%$ and $100 \%$ opening ratios, respectively.

\subsection{Bonding characteristics of the thermo-compre- ssion bonding process}

The bonding result of bonding profile 1 in Table 1 confirmed through the measurement of electric characteristics that no bonding was made. An observation of the fracture surface revealed that the bumps at the center of the chip were not melted. When the bonding was performed with bonding profiles 2 and 3 by increasing the stage temperature of the TC bonding system, the daisy chain resistance of bumps was measured at approximately $1 \Omega$ or lower, thus we confirmed chip-substrate bonding, sucessfully. The result of X-ray analysis of samples fabricated under the conditions of bonding profiles 2-1 and 2-2 showed that there were less voids at the 2-2 joint without flux application as shown in Fig. 9. It was believed that more voids were formed by residues of flux due to the lack of flux reaction time. Furthermore, the fact that bonding profile 3 with a short bonding time showed the smallest number of voids suggest that more voids were formed inside as the solder spread more as the bonding time was longer. The bonding profile 3 was selected as the optimal condition, and the measured temperatures are shown in Fig. 10.

The cross-sectional analysis result of the bonding profile 3 sample showed that all bumps were bonded well at a constant thickness as shown in Fig. 11. However, when the cross-sections of the chip outline were observed, it was found that approximately a half of the $\mathrm{Cu}$ pillar joint was not filled due to insufficient solders as shown in Fig. 12 (a). In contrast, the cross-sectional analysis of the TC bonding to which solder paste printing was applied showed that the solder paste filled the entire area of the joint well and the bonding was performed well as shown in Fig. 12 (b). The EDS analysis result showed that a $\mathrm{Cu}_{6} \mathrm{Sn}_{5}$ IMC layer was formed on

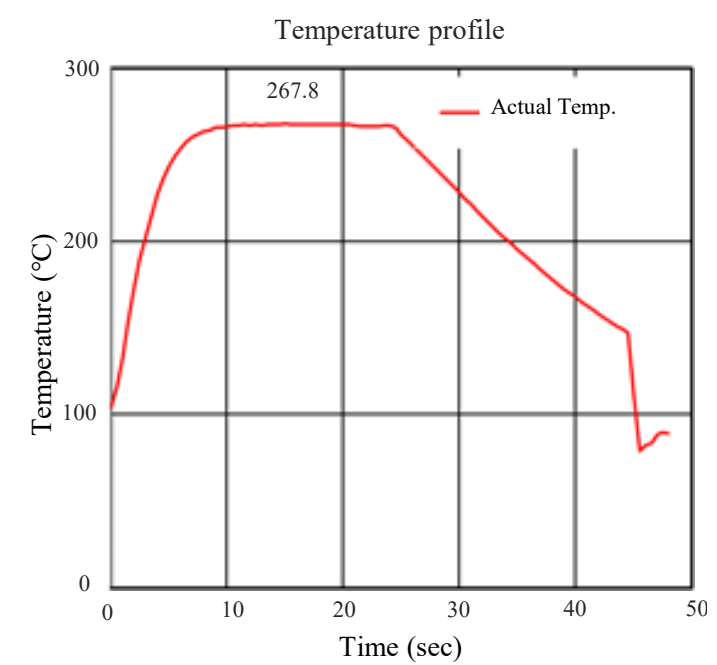

Fig. 10 The measured temperature of bonding profile 3

top of the joint and at the bottom, a $(\mathrm{Cu}, \mathrm{Ni}, \mathrm{Au}, \mathrm{Pd})_{6} \mathrm{Sn}_{5}$ IMC layer was sometimes observed, and it was mainly formed as a $(\mathrm{Cu}, \mathrm{Ni})_{6} \mathrm{Sn}_{5}$ IMC layer. The solder thickness was approximately $4.1 \mu \mathrm{m}$ at the joint of the chip outline, approximately $1.8 \mu \mathrm{m}$ at the top IMC, and approximately $0.9 \mu \mathrm{m}$ at the bottom IMC. After the solder paste printing process was applied, the solder thickness was approximately $6.5 \mu \mathrm{m}$ at the TC bonding, approximately $1.8 \mu \mathrm{m}$ at the top IMC, and approximately 1.2 $\mu \mathrm{m}$ at the bottom IMC.

\subsection{Bonding characteristics of the vacuum reflow bonding process}

Fig. 13 shows the cross-sectional analysis result of bonded samples (a) when the top and bottom surfaces were fixed with set screws and (b) when they were not fixed. For process condition, bonding profile 2 of Fig. 7 was applied. When the substrate was fixed with top and bottom jigs, the bump and pad aligned well. However, when a warpage of the BT substrate occur4red, it was found that the end of the substrat3e was not bonded as shown in Fig. 13 (a). In contrast, when the top and bottom

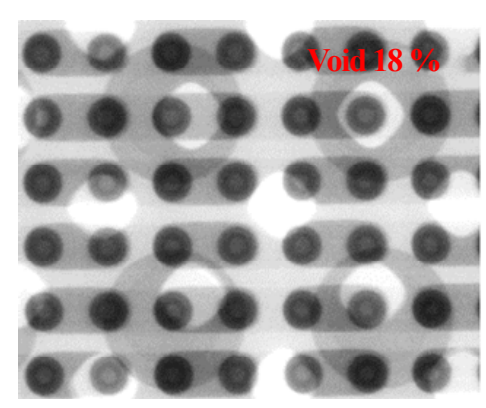

(a)

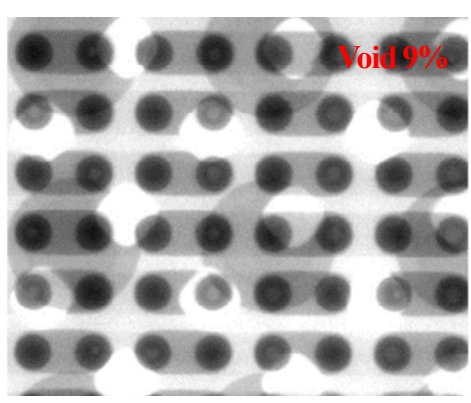

(b)

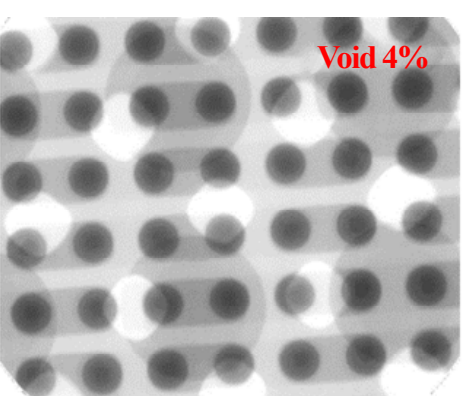

(c)

Fig. 9 X-ray non-destructive analysis images after flip chip-BT substrate TC bonding using by (a) bonding profile 2-1, (b) bonding profile $2-2$ and (c) bonding profile 3 


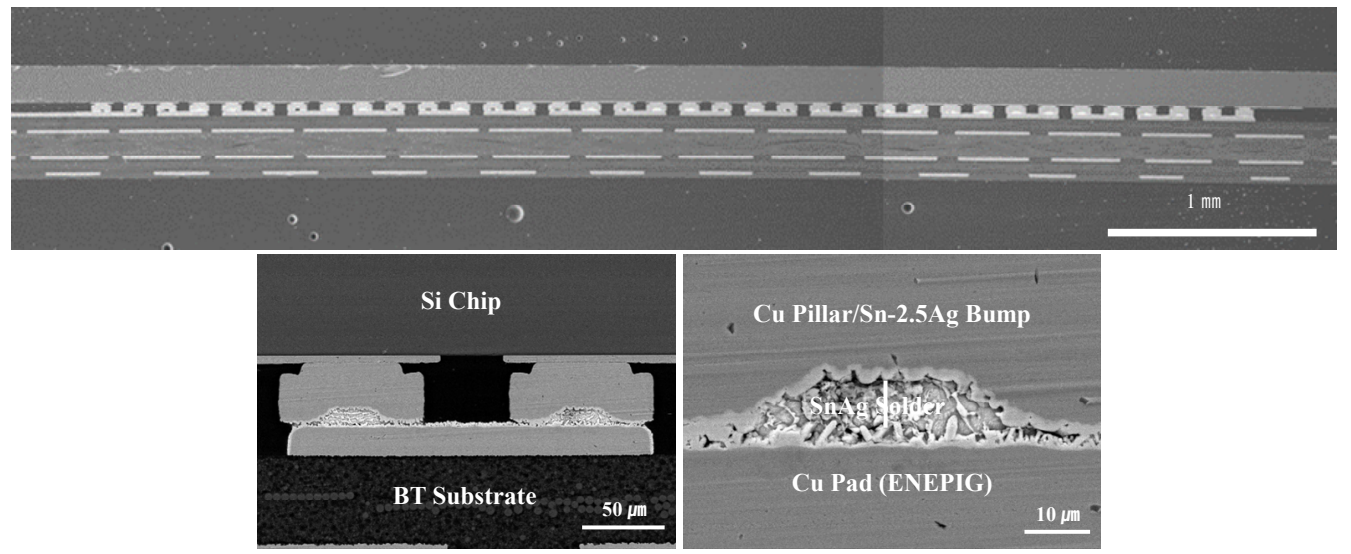

Fig. 11 Cross-sectional SEM micrographs of FC-CSP bonded by profile 3

(a)

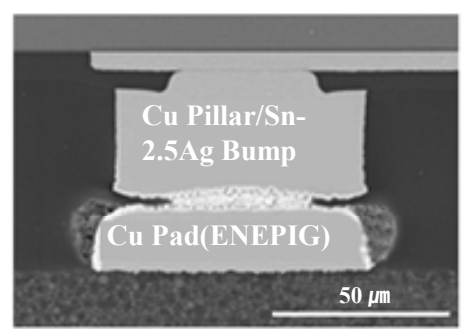

(b)

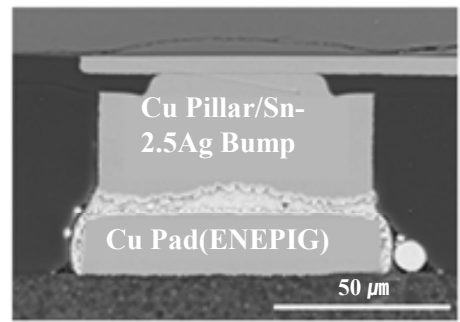

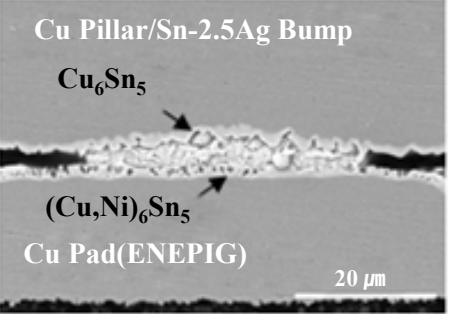

Cu Pillar/Sn-2.5Ag Bump

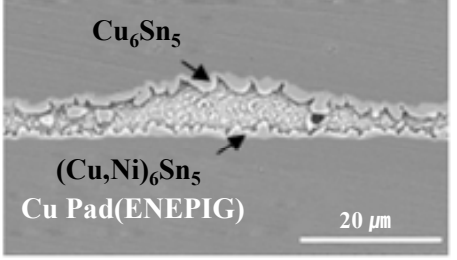

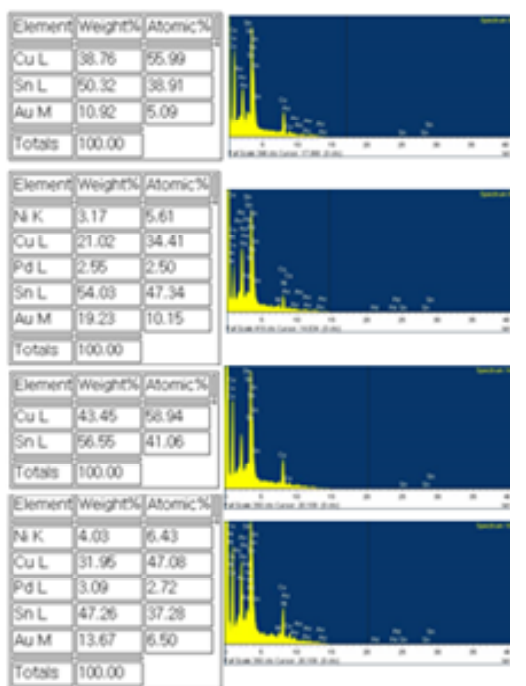

cotsis 100000

Fig. 12 Cross-sectional SEM micrographs and EDS analysis results of thermal compression bonding profile 3 samples: (a) without solder paste and (b) with solder paste

(a)

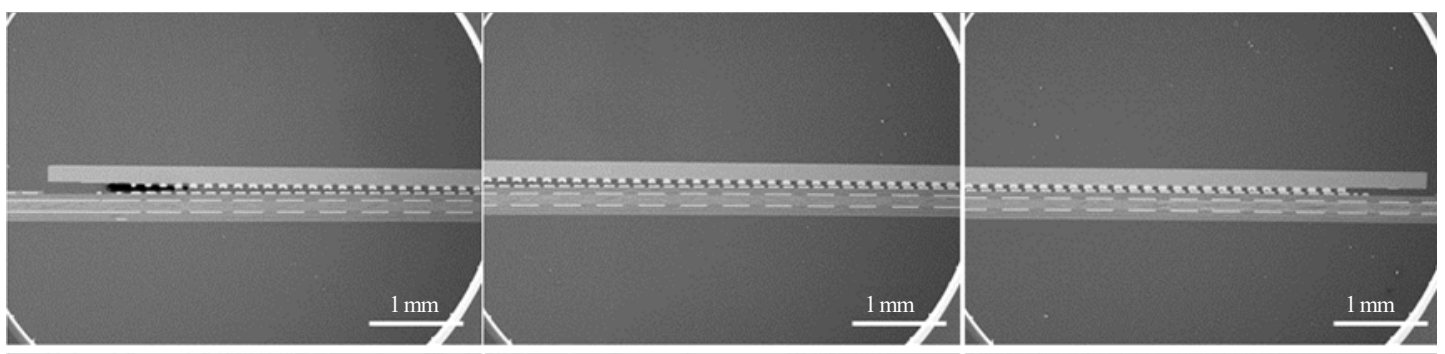

(b)
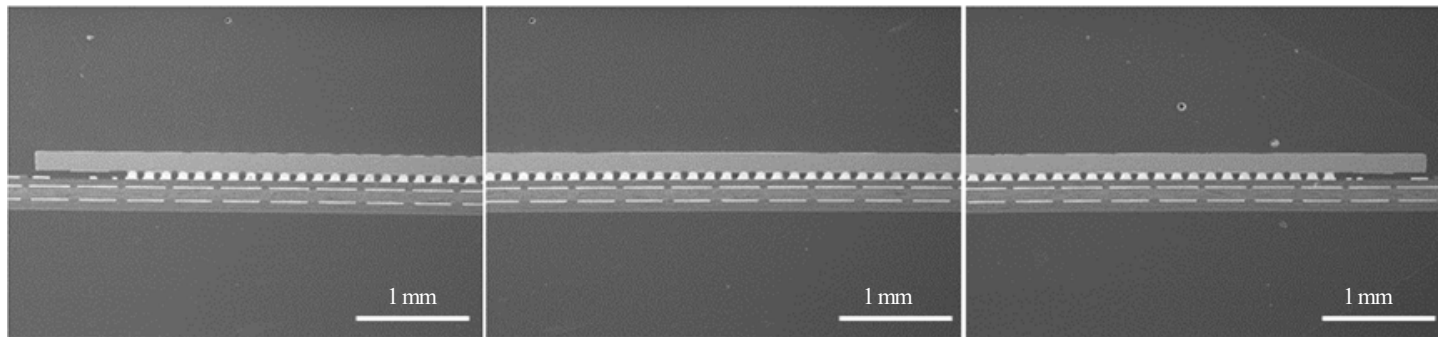

Fig. 13 Cross-sectional SEM micrographs after the vacuum reflow bonding using by bonding

jigs were fixed with screws, the joints were formed well at all bumps of the substrate as shown in Fig. 13 (b). This demonstrated that this jig fixing method is effective for suppressing the warpage of the BT substrate 
during the chip bonding process.

The X-ray analysis results of the joint according to the bonding profile in Fig. 7 are shown in Fig. 14. As a re-
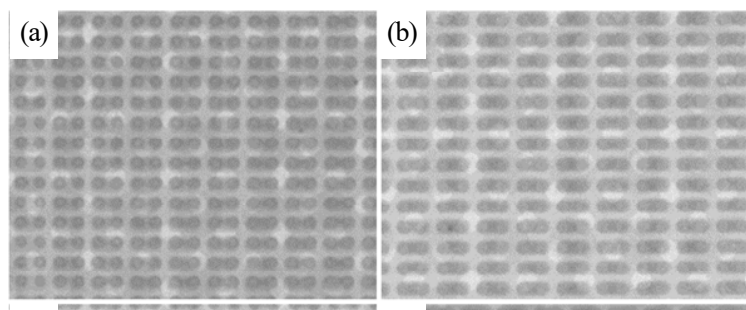

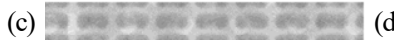

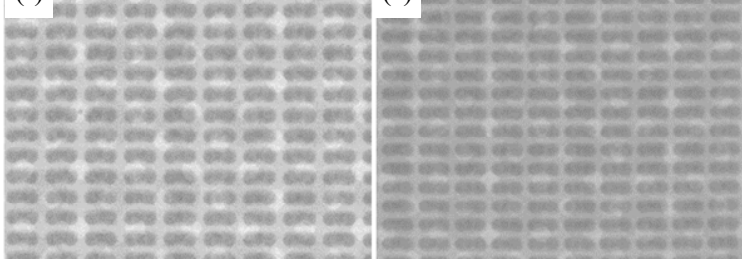

Fig. $14 \mathrm{X}$-ray non-destructive analysis images after the vacuum reflow soldered FC-CSP using by (a) bonding profile 1 , (b) bonding profile 2, (c) bonding profile 3 and (d) bonding profile 4 sult of the X-ray analysis, fewer voids were observed at the joints of bonding profiles 3 and 4 with a shorter warm-up and peak temperature times.

Fig. 15 shows the cross-sectional analysis result of the joint by temperature profile. As a result of the EDS analysis, a $\mathrm{Cu}_{6} \mathrm{Sn}_{5}$ IMC layer was observed at the top, and a $(\mathrm{Cu}, \mathrm{Ni})_{6} \mathrm{Sn}_{5}$ IMC layer was observed at the bottom, the IMC grew rapidly according to the temperature and time of each bonding profile. Bonding profile 4 where micro-voids were not observed and the IMC thickness was the smallest was selected as the optimum condition. The solder thickness was approximately 10.3 $\mu \mathrm{m}$ at the joint of the bonding profile 5 sample, approximately $6 \mu \mathrm{m}$ at the top IMC, and approximately $1.7 \mu \mathrm{m}$ at the bottom IMC.

By process, the solder thickness was $4.1 \mu \mathrm{m}$ at the TC bonded joint, $6.5 \mu \mathrm{m}$ at the TC bonded joint with solder paste printing applied, and $10.3 \mu \mathrm{m}$ at the VR joint. The IMC thickness ratio to the total joint was approximately $40 \%$ at the TC bonded joint, approximately $32 \%$ at the TC bonded joint with solder paste printing applied, and

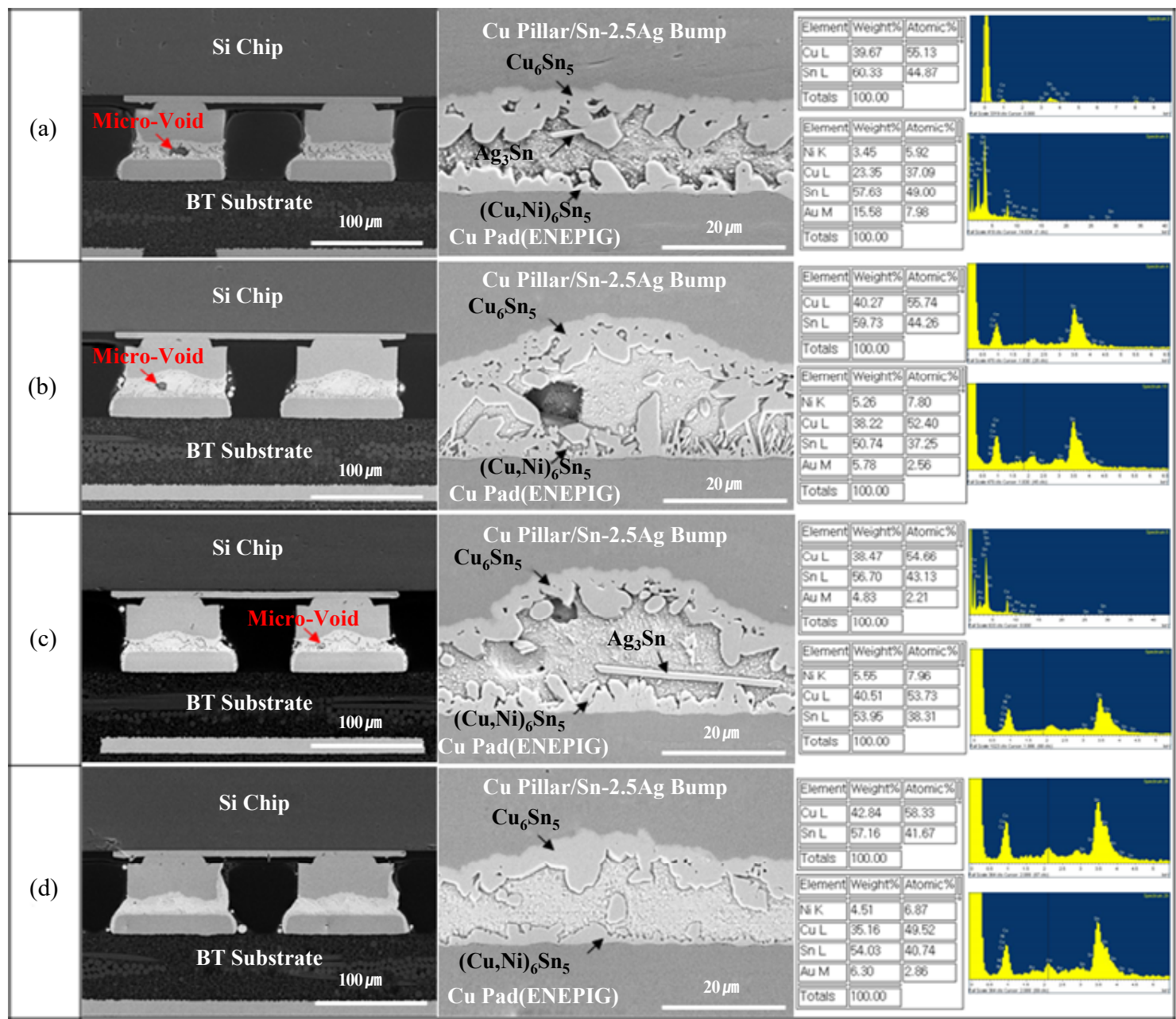

Fig. 15 Cross-sectional SEM micrographs and EDS analysis results after the vacuum reflow soldered FC-CSP using by (a) bonding profile 1 , (b) bonding profile 2, (c) bonding profile 3 and (d) bonding profile 4 
approximately $43 \%$ at the VR joint. According to previous studies, cracks at the TC bonding were caused by ductile failure due to fatigue and spread through micro-voids due to creep, and the cracks of IMC were mainly caused by brittle failure along the interface of $\mathrm{Cu}_{6} \mathrm{Sn}_{5}$ or $\mathrm{Cu}_{3} \mathrm{Sn}^{10)}$. Furthermore, it has been reported that the larger the solder volume at the joint, the lower the generation and spread of cracks at the joint, thus improving fatigue life ${ }^{11)}$. Therefore, it was considered that the VR joint with the largest solder volume and the TC bonding with printing applied, which had the lowest ratio of the IMC thickness, would be more advantageous for reliability than the joint of the conventional TC process. Furthermore, it was also considered that if the VR process temperature was lowered further, the reliability could be improved more effectively.

\section{Conclusions}

This study optimized the thermo-compression bonding process of FC-CSP using a chip with $\mathrm{Sn}-2.5 \mathrm{Ag}$ capped $\mathrm{Cu}$ pillar bumps of $90 \mu \mathrm{m}$ diameter and an ENEPIG-surface-treated BT substrate. TC bonding and VR bonding were performed, and the TC and VR bonding processes of the ternary solder were optimized by applying the printing process of type $7 \mathrm{Sn}-3.0 \mathrm{Ag}-0.5 \mathrm{Cu}$ solder paste.

1) The result of optimizing the printing process using type 5 and type 7 solder pastes, and metal masks of 30 $\mu \mathrm{m}$ and $50 \mu \mathrm{m}$-thicknesses and the opening ratios of 70 $\%$ showed that type 7 solder paste and the metal mask with $30 \mu \mathrm{m}$ thickness and $100 \%$ opening ratio were most appropriate.

2) The bonding process was optimized by applying TC bonding with flip chip-BT substrate bonding process, TC bonding with solder paste printing process, and VR bonding process. A $\mathrm{Cu}_{6} \mathrm{Sn}_{5}$ IMC layer was formed at top of the joint, and a $(\mathrm{Cu}, \mathrm{Ni})_{6} \mathrm{Sn}_{5}$ IMC layer was formed at the bottom. The thicknesses of the solder joint were $4.1 \mu \mathrm{m}, 6.5 \mu \mathrm{m}$, and $10.3 \mu \mathrm{m}$, respectively, and the IMC thickness ratios were approximately $40 \%, 32$ $\%$, and $43 \%$, respectively.

3) The result of the TC and VR bonding processes with type 7 solder paste printing showed that the solder volume increased compared to the conventional TC process and this had an effect of decreasing the IMC thickness ratio. This was considered to be advantageous for reliability by decreasing the generation and spread of cracks due to the effect of lowering the IMC thickness ratio resulting from the increased solder volume compared to the conventional TC process.

\section{Acknowledgments}

This research was conducted with the funding from the Material and Components Technology Development Project (Project number: 20011427) supported by the Ministry of Trade, Industry and Energy.

ORCID: Mi-Song Kim: https://orcid.org/0000-0002-4717-9365 ORCID: Won Sik Hong: http://orcid.org/0000-0001-8398-177X ORCID: Myeongin Kim: https://orcid.org/0000-0002-5151-1404

\section{References}

1. S. H. Ahn, Fine Pitch Surface Mount Technology, J. Korean Weld. Join. Soc. 13(4) (1995) 30-35.

2. S. H. Yoo and C. W. Lee, Through Silicon Via Filling and Fine Pitch Joining Technology for 3D Electronic Package, J. Korean Weld. Join. Soc. 27(3) (2009) 17-22.

3. M. J. Lee, M. Yoo, J. H. Cho, S. K. Lee, J. D. Kim, C. H. Lee, D. B. Kang, C. Zwenger, and R. Lanzone, Study of Interconnection Process for Fine Pitch Flip Chip, Proceedings of Electronic Components and Technology Conference (ECTC), IEEE 60th (2009) 234-239. https://doi.org/10.1109/ECTC.2009.5074092

4. M. S. Kim, M. S. Kang, J. H. Bang, C. W. Lee, M. S. Kim, and S. H. Yoo, Interfacial Reactions of Fine-Pitch $\mathrm{Cu} / \mathrm{Sn}$ - 3.5Ag Pillar Joints on $\mathrm{Cu} / \mathrm{Zn}$ and $\mathrm{Cu} / \mathrm{Ni}$ Under Bump Metallurgies, J. Alloys Compd. 616 (2014) 394-400. http://dx.doi.org/10.1016/j.jallcom.2014.07.124

5. K. S. Choi, H. Lee, H. C. Bae, and Y. S. Oem, Recent Trends of Flip Chip Bonding Technology, Electron. Telecommun. Trends, 28(5) 100-110.

6. S. J. Kim, W. S. Hong, H. B. Nam, and N. H. Kang, Growth Behavior of Intermetallic Compounds in Various Solder Joints Induced by Electromigration, J. Weld. Join. 39(1) (2021) 89-102. https://doi.org/10.5781/JWJ.2021.39.1.11

7. J. H. Back, S. H. Yoo, D. G. Han, S. B. Jung, and J. W. Yoon, Effect of Thin ENEPIG Plating Thickness on Interfacial Reaction and Brittle Fracture Rate of Sn3.0Ag-0.5Cu Solder Joints, J. Weld. Join. 36(5) (2018) 52-60.

https://doi.org/10.5781/JWJ.2018.36.5.7

8. S. S. Ha, D. G. Kim, J. W. Kim, J. W. Yoon, J. H. Joo, Y. E. Shin, and S. B. Jung, Interfacial Reaction and Joint Reliability of Fine-Pitch Fip-Chip Solder Bump Using Stencil Printing Method, J. Microelectron. Eng. 84 (2007) 2640-2645.

https://doi.org/10.1016/j.mee.2007.05.062

9. J. H. Back, S. H. Yoo, D. G. Han, S. B. Jung, and J. W. Yoon, Interfacial Reactions and Mechanical Strength of Sn-3.0Ag-0.5Cu/0.1 $\mu \mathrm{m}-\mathrm{Ni}$ Thin ENEPIG Solder Joints, J. Weld. Join. 35(6) (2017) 51-58. https://doi.org/10.5781/JWJ.2017.35.6.8 
10. J. Li, Y. Zhang, H. Zhang, Z. Chen, C. Zhou, and X. Liu, W. Zhu, The Thermal Cycling Reliability of Copper Pillar Solder Bump in Flip Chip Via Thermal Compression Bonding, J. Trans. Microelectron. Reliab. 104 (2020) 1-12.

https://doi.org/10.1016/j.microrel.2019.113543
11. K.Y. Au, F. X. Che, J. K. Lin, H. Y. Hsiao, X. Zhang, S. Lim, J. L. Aw, and A. Chow, Thermal Compression Bonding of $30 \mu \mathrm{m}$ Pitch Cu Pillar Microbump on Organic Substrate with Bare Cu Bondpad, Proceedings of Electronic Components and Technology Conference (ECTC), IEEE 66th (2016) 936-942.

https://doi.org/10.1109/ECTC.2016.127 


\title{
Type 7 솔더 페이스트 프린팅 공정을 적용한 플립칩 - 칩 스케일 패키지 접합기술
}

\section{Flip Chip - Chip Scale Package Bonding Technology with Type 7 Solder Paste Printing}

\author{
김 미 송*·홍 원 식*·김 명 인* \\ *한국전자기술연구원 융복합전자소재연구센터
}

1. 서 론

전자제품의 고기능화, 소형화에 따라 반도체 패키지의 I/O 수는 증가하고 있으며, 인터커넥션(interconnection) 의 고밀도화가 요구되고 있다. 반도체 패키지의 인터커 넥션 기술은 칩(chip)과 기판(substrate)의 전극을 와 이어(wire)로 연결하는 와이어 접합 기술과 칩과 기판 의 전극을 솔더(solder) 접합으로 연결하는 플립칩 (flip chip) 접합기술이 있다. 플립칩 접합기술은 칩의 전면을 사용할 수 있기 때문에 와이어 접합기술보다 많 은 I/O 수를 연결할 수 있고, 와이어 길이보다 약 10 배 이상 짧으므로 신호 처리가 빠르다는 장점이 있다. 따라서 $\mathrm{I} / \mathrm{O}$ 수가 많은 고집적 패키지나 고속 신호 처 리가 필요한 디지털 패키지의 인터커넥션 기술로 다양 하게 적용되고 있다(Fig. 1 $)^{1-5)}$.

고밀도 $\mathrm{I} / \mathrm{O}$ 패키지를 위해서는 접합부 범프(bump) 의 피치(pitch)를 줄이는 연구가 필요하며, 보통 $150 \mu \mathrm{m}$ 이상의 범프 크기에서는 솔더 페이스트(solder paste) 의 프린팅(printing) 공정이나 솔더 볼(solder ball) 을 적용한다. $150 \mu \mathrm{m}$ 이하로 범프의 피치가 작아질 경 우 솔더 브릿지 (solder bridge)로 인한 전기적 단락이 발생할 수 있으므로 솔더 증착이나 도금 방법을 이용하 는데, 범프 크기가 작아지면서 접합부의 높이가 낮아지 므로 $140 \mu \mathrm{m}$ 이하의 피치에서는 신뢰성 확보와 언더필 (underfill) 충진이 어려워진다. 따라서 $140 \mu \mathrm{m}$ 이하의 범프 피치에서는 $\mathrm{Cu}$ 필러(pillar)에 $\mathrm{Sn}$ 계 솔더 캡(cap) 을 형성한 $\mathrm{Cu}$ pillar 범프 기술을 적용한다(Fig. 1) ${ }^{1-5)}$.

$\mathrm{Cu}$ 전극 패드 $(\mathrm{pad})$ 와 $\mathrm{Cu}$ pillar 범프가 접합했을 때 $\mathrm{Cu}-\mathrm{Sn}$ 계 금속간화합물(Intermetallic compound, $\mathrm{IMC)}$ )이 형성되는데, 범프의 크기가 작을수록 접합부 에서 $\mathrm{IMC}$ 가 차지하는 비중이 증가함에 따라 신뢰성에 취약해진다. 이러한 문제점을 개선하기 위해서 미세 피 치의 $\mathrm{Cu}$ 전극 패드에 확산 방지층 역할을 하는 $\mathrm{Ni}$ 층 을 도금으로 형성하거나, 신뢰성이 우수한 3원계 솔더

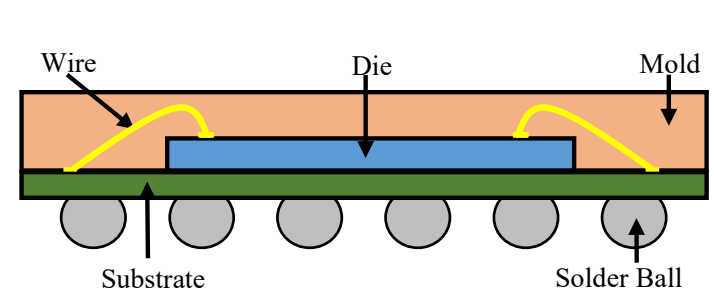

(a)

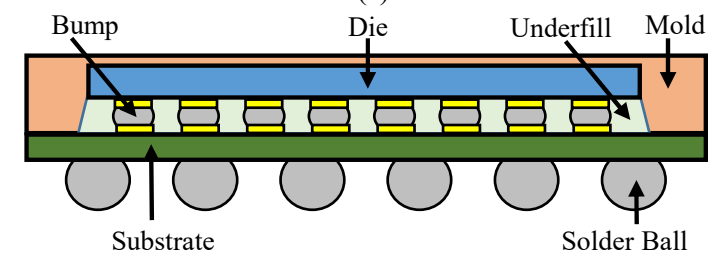

(b)

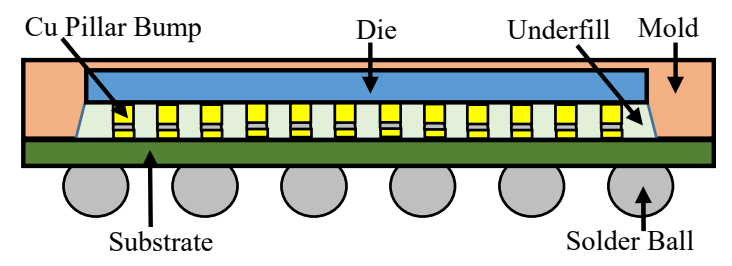

(c)

Fig. 1 Schematic structural diagram of (a) wire bonding package, (b) flip chip-chip scale package (FCCSP) and (c) fine pitch FCCSP

를 도금한 $\mathrm{Cu}$ pillar 범프를 형성한다. 하지만 일반적 으로 3 원계 도금은 도금액 관리에 어려움이 있어서 양 산성이 높지 않다는 단점이 크기 때문에, 주로 $\mathrm{Cu}$ 전극 패드에 ENIG (electroless-nikel immersion-gold) 및 ENEPIG (electroless-nikel electroless-palladium immersion-gold) 등의 표면처리 방법이 적용된다. 특 히, ENEPIG 기술은 ENIG 접합부에서 발생하는 커 켄달 보이드(kirkendall void)의 형성을 억제하여 기 계적 신뢰성이 더 우수한 것으로 보고되고 있다 ${ }^{5-9}$.

본 연구에서는 $150 \mu \mathrm{m}$ 피치의 $\mathrm{Cu}$ pillar $\mathrm{Sn}-2.5 \mathrm{Ag}$ 범프가 형성된 칩과 ENEPIG 표면처리 된 $\mathrm{BT}\left(\mathrm{bis}^{-}\right.$ maleimide triazine) substrate를 사용하여 플립칩 칩스케일 패키지(flip chip-chip scale package, $\mathrm{FC}^{-}$ 
$\mathrm{CSP}$ )의 열압착 접합공정을 최적화하였다. 또한 Type 7 의 $\mathrm{Sn}-3.0 \mathrm{Ag}-0.5 \mathrm{Cu}$ 솔더 페이스트를 이용한 3 원계 무연솔더를 적용한 열압착(thermo compression, TC) 및 진공 리플로우(vacuum reflow, VR) 접합공정 최 적화에 대한 연구를 하였다.

\section{2. 실험 방법}

\section{1 원부자재 분석}

실험에 사용된 기판은 Fig. 2 와 같이 $15 \times 15 \mathrm{~mm}$ 크기의 ENEPIG 표면처리된 BT substrate를 사용하 였고, 기판의 두께는 $0.3 \mathrm{~mm}$, 표면처리 두께는 $\mathrm{Ni}$ 3-8 $\mu \mathrm{m}, \mathrm{Pd} 0.05-0.15 \mu \mathrm{m}, \mathrm{Au} 0.05-0.15 \mu \mathrm{m}$ 이였 다. 사용된 칩은 Fig. 3 과 같이 1,744 개의 직경 $90 \mu \mathrm{m}$, 피치 $150 \mu \mathrm{m}$, 높이 약 $50 \mu \mathrm{m}$ 의 $\mathrm{Cu}$ pillar $/ \mathrm{Sn}-2.5 \mathrm{Ag}$ 범프가 형성된 $10 \times 15 \mathrm{~mm}$ 크기의 칩을 사용하였다. 솔더 페이스트는 $\mathrm{Sn}-3.0 \mathrm{Ag}-0.5 \mathrm{Cu}$ (MKE Co. Ltd., Korea) 조성을 사용하였고, Type 5와 Type 7을 이 용하여 프린팅 공정성을 평가하였다. Fig. 4와 같이 Type 5와 Type 7의 솔더 볼 크기는 각각 15-25 $\mu \mathrm{m}$, 2-11 $\mu \mathrm{m}$ 를 만족하는 것을 확인하였다.

\section{2 지그 설계 및 제작}

Fig. 5와 같이 미세 피치 솔더 페이스트 프린팅을 위 해 미세 조정이 가능한 프린팅 지그를 제작하였고, 메 탈마스크(metal mask) 두께는 $50 \mu \mathrm{m}$ 및 $30 \mu \mathrm{m}$, 개
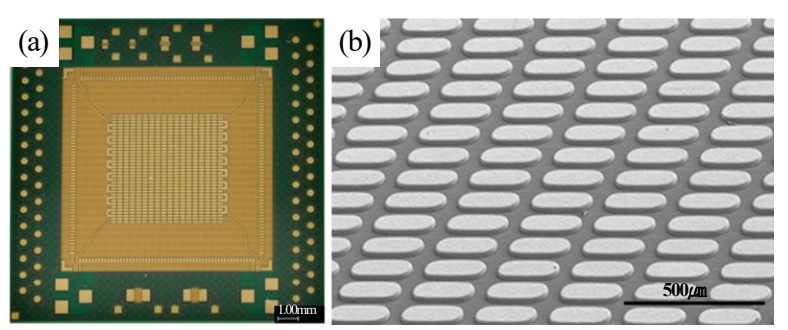

Fig. 2 Optical and SEM micrographs of BT substrate for FC-CSP, (a) top side and (b) magnified ENEPIG pad
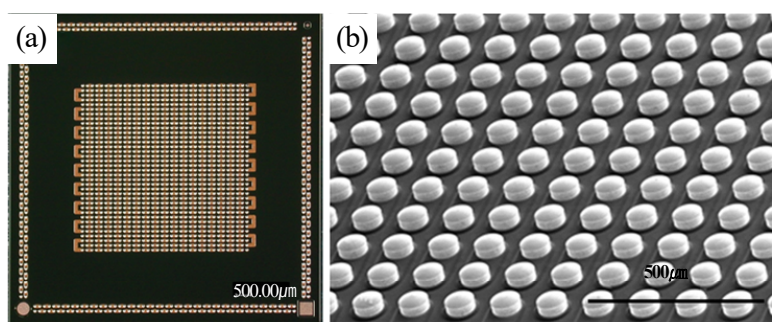

Fig. 3 Optical and SEM micrographs of Si flip chip, (a) bump side and (b) magnified $\mathrm{Cu}$ pillar bump

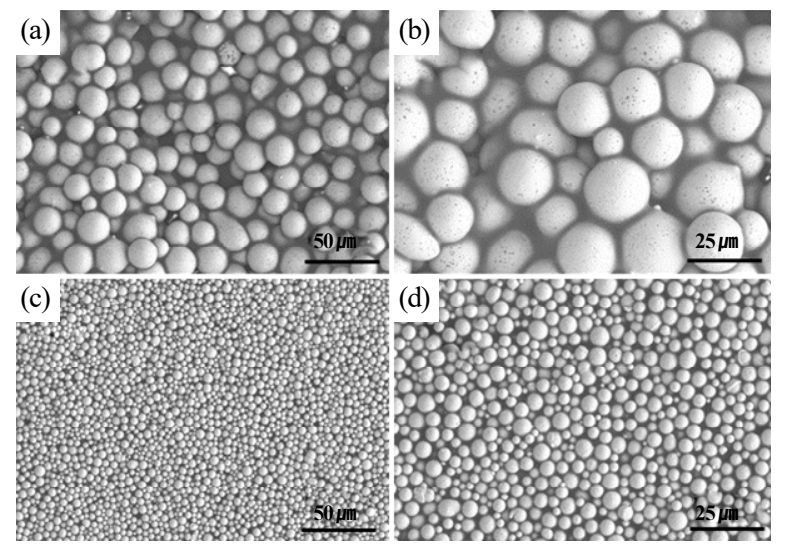

Fig. 4 SEM micrographs of solder pastes, $(a, b)$ Type 5 and $(\mathrm{c}, \mathrm{d})$ Type 7

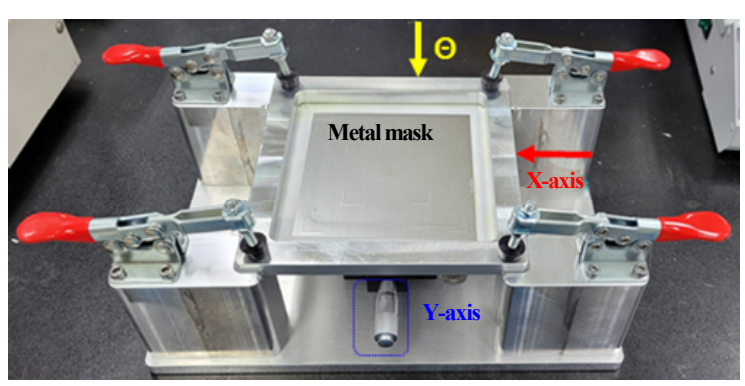

Fig. 5 Photograph of Photograph of printing jig with $\mathrm{X} / \mathrm{Y} /$ $\Theta$ axis adjustment for solder paste printing on the FC-CSP substrate

구율은 $70 \%$ 및 $100 \%$ 로 제작하였다. 미세 피치 $\mathrm{FC}-\mathrm{CSP}$ 칩의 리플로우 접합을 위해서는 범프의 위치 (align)를 고정할 수 있는 지그가 필요하며, Fig. 6과 같이 지그를 제작하였다. 프린팅 후 $\mathrm{FC}-\mathrm{CSP}$ 칩을 고 정할 수 있는 형태로 지그를 제작하였으며, BT substrate 특성상 고온에서 휨(warpage)이 발생을 억제할 수 있도록 substrate 고정이 가능한 지그를 제작하였다.

\section{3 솔더 페이스트 프린팅}

Type 5 및 Type 7 솔더 페이스트의 분말 입도, metal mask 두께 및 개구율에 따른 프린팅 인쇄성을 평가하여, 브릿지 등 불량이 발생하지 않는 최적의 솔 더 페이스트와 metal mask를 선정하였다.

\section{4 열압착 접합}

열압착(thermo compression, $\mathrm{TC}$ ) 접합공정은 플립 칩 본더(NM-SB50A, Panasonic Co. Ltd., Japan) 장비를 이용하였고, 접합 후 daisy chain으로 연결된 모든 범프의 전기적 특성을 측정하여 chip-substrate 접합 상태를 판단하였다. 공정조건은 Table 1 과 같고, 

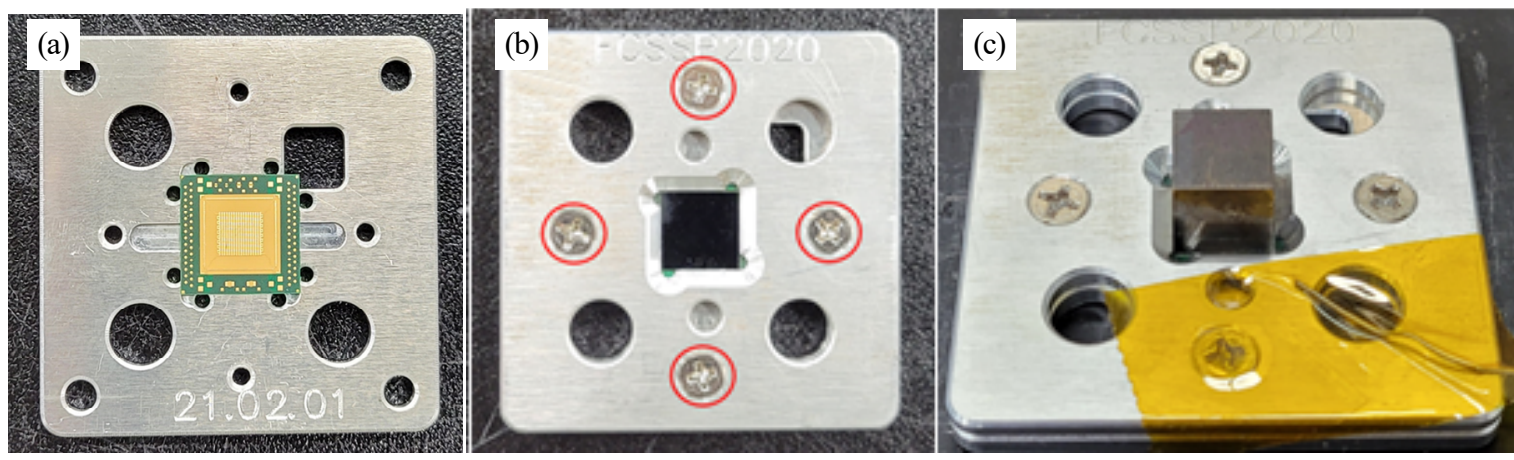

Fig. 6 Photographs of vacuum reflow bonding jig, (a) Lower jig, (b) upper jig and (c) weight compression after the jig joining

Table 1 The temperature and the pressure profile condition for thermo-compression bonding

\begin{tabular}{|c|c|c|c|c|c|}
\hline Bonding profile & Stage Temp. $\left({ }^{\circ} \mathrm{C}\right)$ & Head Temp. $\left({ }^{\circ} \mathrm{C}\right)$ & Time $(\mathrm{sec})$ & Load $(\mathrm{N})$ & Flux \\
\hline 1 & 80 & 320 & 35 & 10 & $\mathrm{x}$ \\
\hline $2-1$ & 100 & 320 & 35 & 10 & $\mathrm{o}$ \\
\hline $2-2$ & 100 & 320 & 35 & 10 & $\mathrm{x}$ \\
\hline 3 & 100 & 320 & 15 & 10 & $\mathrm{x}$ \\
\hline
\end{tabular}

bonding profile 2-1 및 2-2와 같이 플럭스(flux)를 도포한 샘플과 도포하지 않은 샘플을 제작하여 보이드 (void) 특성을 평가하였다. $\mathrm{Cu}$ pillar/ $\mathrm{Sn}-2.5 \mathrm{Ag}$ 범 프가 형성된 칩과 $\mathrm{BT}$ substrate의 $\mathrm{TC}$ 접합공정을 최 적화하였고, 추가적으로 Type $7 \mathrm{Sn}-3.0 \mathrm{Ag}-0.5 \mathrm{Cu}$ 솔더 페이스트를 프린팅한 후 $\mathrm{TC}$ 접합하여 접합부의 미세조직을 비교하였다.

\section{5 진공 리플로우 접합}

진공 리플로우(vacuum reflow, VR) 접합공정은 RSS-210-S(UniTemp) 장비를 이용하였고, 공정조건 은 Fig. 7과 같았다. Fig. 7의 (e)와 같이 승온 속도, soak 시간, peak 온도 및 시간을 변화하면서 접합부 특성을 분석하였고, 지그 표면의 실측 온도는 $(\mathrm{a}-\mathrm{d})$ 와 같이 측정되었다. 질소 분위기에서 시작하여 peak 온 도 구간에서는 진공 분위기를 조성하였고, 질소를 주입 하여 cooling을 진행하였다. 접합공정 중에는 $18 \mathrm{~g}$ 무 게의 추로 칩을 가압하며 $0.18 \mathrm{~N}$ 의 하중으로 접합공 정을 진행하였고, 지그의 상하면을 나사로 가압한 경우 와 없는 경우의 샘플을 제작하여 접합부를 비교하였다.

\section{3. 실험 결과}

\section{1 프린팅 공정 특성}

솔더 페이스트의 종류, metal mask의 두께 및 개구
율에 따른 프린팅 공정 결과를 Fig. 8에 나타내었다. Type 5 솔더 페이스트를 프린팅 했을 때 (a)와 같이 솔더 볼이 잘 빠지지 못한 것을 알 수 있었고, $50 \mu \mathrm{m}$ 의 metal mask를 사용했을 때 프린팅이 고르게 되지 않는 것을 알 수 있었다. 최종적으로 Type $7 \mathrm{Sn}-3.0 \mathrm{Ag}^{-}$ $0.5 \mathrm{Cu}$ 솔더 페이스트 및 $30 \mu \mathrm{m}$ 의 metal mask를 선 정하였고, $70 \%$ 와 $100 \%$ 의 개구율로 각각 프린팅 하였다.

\section{2 열압착 접합공정의 접합특성}

Table 1의 bonding profile 1 접합 결과 전기적 특 성 측정을 통해 접합되지 않은 것을 확인하였고, 파단 면 관찰 결과 칩 중심부의 범프가 용융되지 않은 것이 관찰 되었다. $\mathrm{TC}$ 접합장비의 stage 온도를 높여 bonding profile 2 와 3 으로 접합한 결과, 범프의 daisy chain 저항이 약 $1 \Omega$ 이하로 측정되어 chip-substrate 접합을 확인하였다. Bonding profile 2-1 및 2-2 조건으로 제작된 샘플의 X-ray 분석 결과 Fig. 9 와 같이 flux를 도포하지 않은 2-2 접합부에서 void가 더 적게 관찰되었다. Flux의 반응시간이 부족하여 flux 잔존으로 인한 void가 더 많이 형성된 것으로 생각되 었다. 또한 접합 시간이 짧았던 bonding profile 3 에 서 void가 가장 적은 것으로 보아, 솔더 양이 충분하지 못할 때 접합시간이 길수록 솔더가 퍼지면서 내부의 void를 더 많이 형성하는 것을 알 수 있었다. Bonding profile 3 조건을 최적 조건으로 선정하였고, 실측 온 

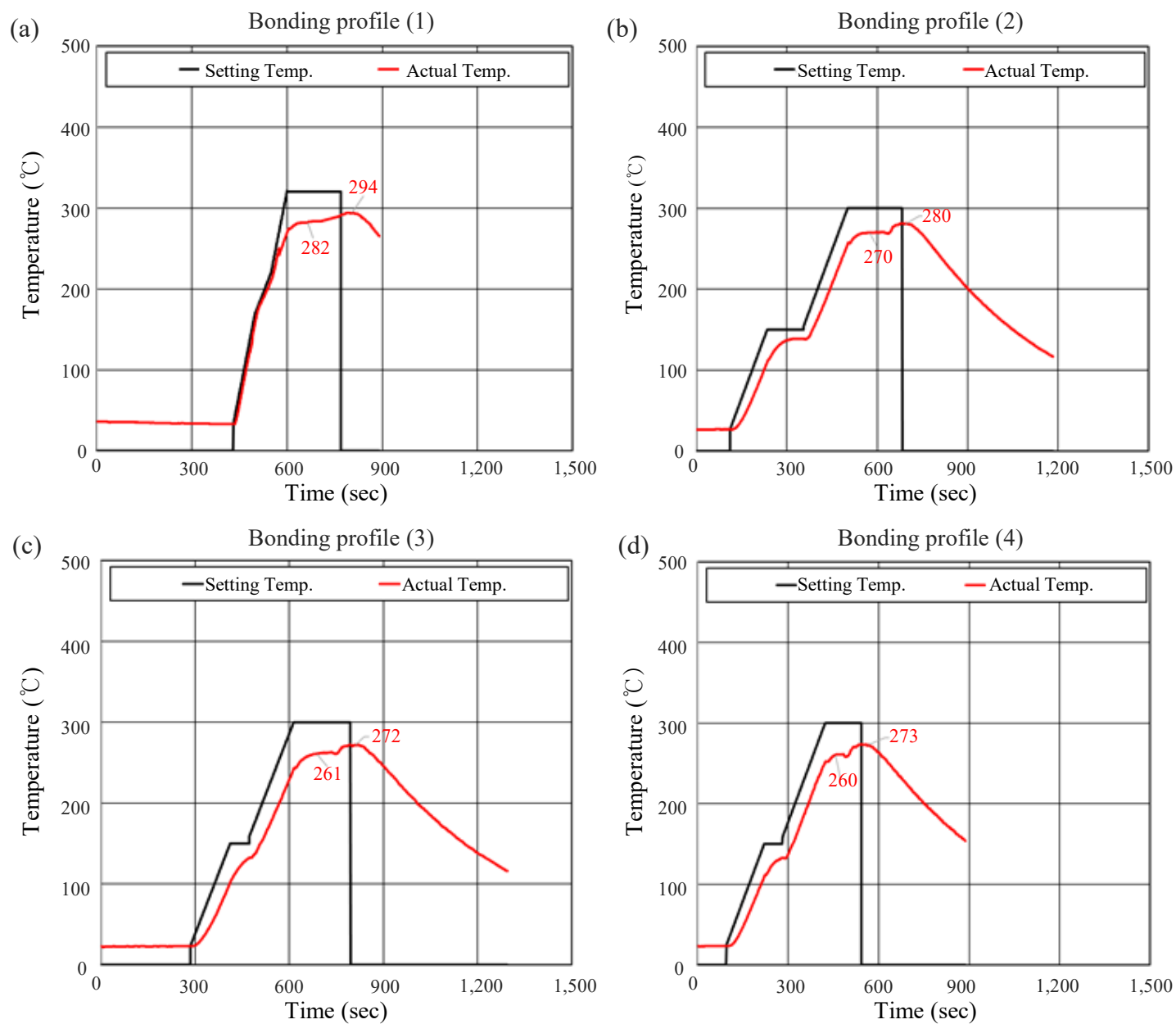

(e)

\begin{tabular}{|c|c|c|c|c|}
\hline Profile No. & $\mathbf{1}$ & $\mathbf{2}$ & $\mathbf{3}$ & $\mathbf{4}$ \\
\hline Soak zone & - & $120 \mathrm{sec}$. at $150{ }^{\circ} \mathrm{C}$ & \multicolumn{2}{|c|}{$60 \mathrm{sec}$ at $150{ }^{\circ} \mathrm{C}$} \\
\hline Peak zone & $130 \mathrm{sec}$ at $320{ }^{\circ} \mathrm{C}$ & $180 \mathrm{sec}$ at $300{ }^{\circ} \mathrm{C}$ & $180 \mathrm{sec}$ at $300{ }^{\circ} \mathrm{C}$ & 120 sec. at $300{ }^{\circ} \mathrm{C}$ \\
\hline Ramp up rate & $2{ }^{\circ} \mathrm{C} / \mathrm{sec}$. & \multicolumn{3}{|c|}{$1{ }^{\circ} \mathrm{C} / \mathrm{sec}}$. \\
\hline
\end{tabular}

Fig. 7 Bonding profiles of vacuum reflow bonding, (a-d) set and measured temperature and (e) profile condition

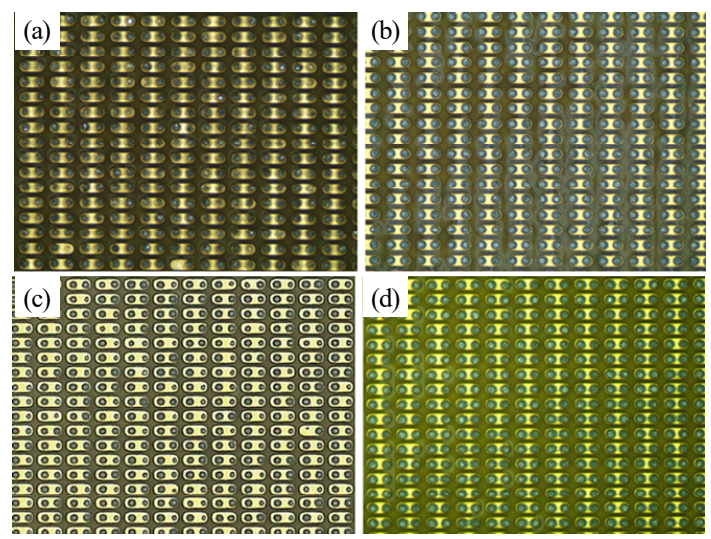

Fig. 8 Optical micrographs after solder paste printing on the pad of BT substrate, (a) Type 5 solder paste, $30 \mu \mathrm{m} / 70 \%$ metal mask, (b) Type 7 solder paste, $30 \mu \mathrm{m} / 70 \%$ metal mask, (c) Type 7 solder paste, $50 \mu \mathrm{m} / 70 \%$ metal mask and (d) Type 7 solder paste, $30 \mu \mathrm{m} / 100 \%$ metal mask
도는 Fig. 10과 같다.

Bonding profile 3 샘플의 단면분석 결과 Fig. 11 과 같이 모든 범프가 일정한 두께로 접합이 잘 되었지 만, 칩 외곽라인의 단면 관찰 결과 Fig. $12(\mathrm{a})$ 와 같이 솔더가 충분하지 않아서 $\mathrm{Cu}$ pillar 접합부의 약 $1 / 2$ 이 채워지지 않은 것을 관찰할 수 있었다. 반면 솔더 페이 스트 프린팅을 적용한 $\mathrm{TC}$ 접합부의 단면분석 결과 Fig. 12(b)와 같이 솔더 페이스트가 접합부의 전면적 을 잘 채워주었고, 접합이 잘 된 것을 확인하였다. $\mathrm{EDS}$ 분석 결과 접합부 상부에는 $\mathrm{Cu}_{6} \mathrm{Sn}_{5} \mathrm{IMC}$ 층이 형성되 었고, 하부에는 간혹 $(\mathrm{Cu}, \mathrm{Ni}, \mathrm{Au}, \mathrm{Pd})_{6} \mathrm{Sn}_{5} \mathrm{IMC}$ 층이 관찰되었고, 주로 $(\mathrm{Cu}, \mathrm{Ni})_{6} \mathrm{Sn}_{5} \mathrm{IMC}$ 층으로 형성된 것을 확인되었다. 칩 외곽라인의 $\mathrm{TC}$ 접합부에서 솔더 의 두께는 약 $4.1 \mu \mathrm{m}$, 상부 $\mathrm{IMC}$ 약 $1.8 \mu \mathrm{m}$, 하부 $\mathrm{IMC}$ 약 $0.9 \mu \mathrm{m}$ 으로 측정되었고, 솔더 페이스트 프린팅 공정 


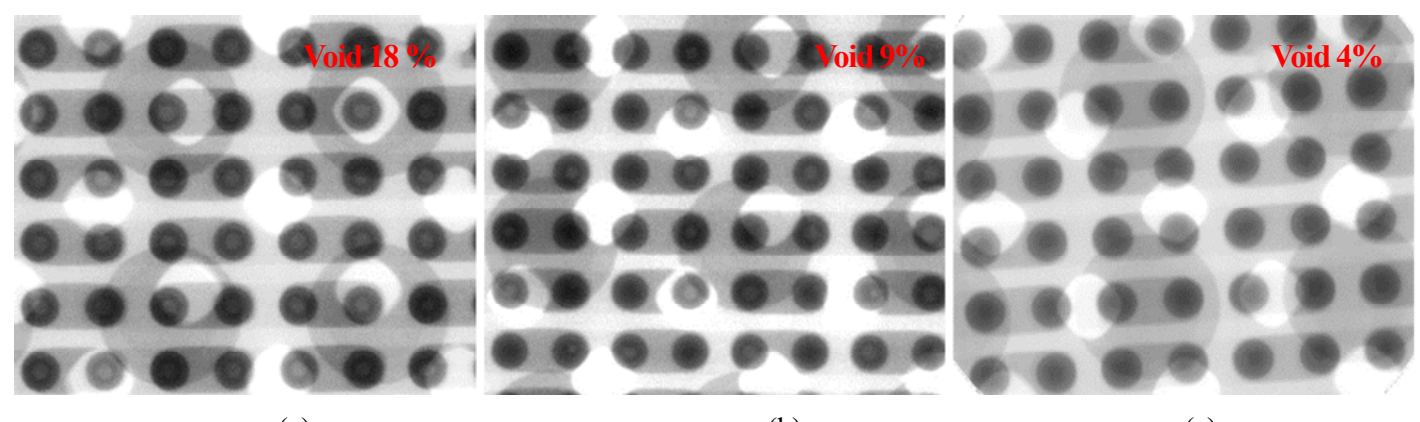

(a)

(b)

(c)

Fig. 9 X-ray non-destructive analysis images after flip chip-BT substrate TC bonding using by (a) bonding profile 2-1, (b) bonding profile $2-2$ and (c) bonding profile 3

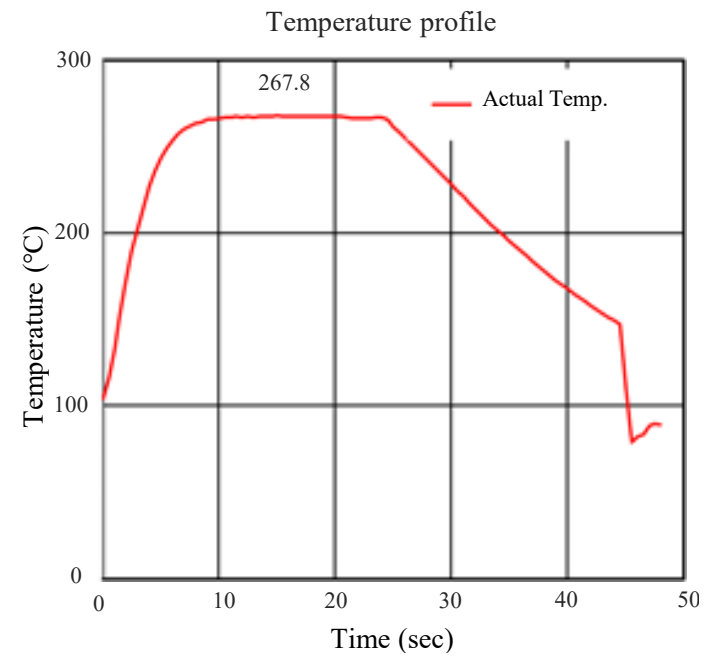

Fig. 10 The measured temperature of bonding profile 3

을 적용한 $\mathrm{TC}$ 접합부에서 솔더의 두께는 약 $6.5 \mu \mathrm{m}$, 상 부 $\mathrm{IMC}$ 약 $1.8 \mu \mathrm{m}$, 하부 $\mathrm{IMC}$ 약 $1.2 \mu \mathrm{m}$ 로 측정되었다.

\section{3 진공 리플로우 접합공정의 접합부 특성}

Fig. 13 은 지그의 상하면을 고정나사로 고정 했을 때 (a)와 고정하지 않았을 때 (b)의 접합된 샘플의 단면
분석 결과이다. 공정 조건은 Fig. 7의 bonding profile 2 를 적용하였다. 기판을 상하면 지그로 고정했을 때 범프와 패드의 align은 잘 일치했지만, $\mathrm{BT}$ substrate의 warpage가 발생하면서 Fig. 13(a)와 같이 기판의 끝부분이 접합되지 않은 것을 알 수 있었다. 반 면 상하면 지그를 나사로 고정했을 때 Fig. 13(b)와 같이 기판의 모든 범프에서 접합부가 잘 형성된 것을 확인 하였고, 이러한 지그 고정방법이 BT substrate 의 warpage 억제에 효과적인 것을 알 수 있었다.

Fig. 7의 bonding profile에 따른 접합부의 X-ray 분석 결과를 Fig. 14에 나타내었다. 분석 결과 예열 시 간 및 peak 온도 시간이 짭았던 bonding profile 3과 4 샘플의 접합부에서 void가 적게 관찰되었다.

Fig. 15는 온도 프로파일에 따른 접합부 단면분석 결과를 나타내었다. $\mathrm{EDS}$ 분석 결과 상부에서 $\mathrm{Cu}_{6} \mathrm{Sn}_{5}$ $\mathrm{IMC}$ 층이 관찰되었고, 하부에서 $\left(\mathrm{Cu}, \mathrm{Ni}_{6}\right)_{6} \mathrm{Sn}_{5} \mathrm{IMC}$ 층이 관찰되었다. 각 bonding profile의 온도 및 시간 에 따라 IMC 성장이 급격하게 일어나는 것을 알 수 있었다. 최적 조건은 micro-void가 관찰되지 않고, IMC 두께가 가장 얇았던 bonding profile 4 로 선정하였다. Bonding profile 5 샘플의 접합부에서 솔더의 두께는 약 $10.3 \mu \mathrm{m}$, 상부 IMC 약 $6 \mu \mathrm{m}$, 하부 IMC 약 $1.7 \mu \mathrm{m}$

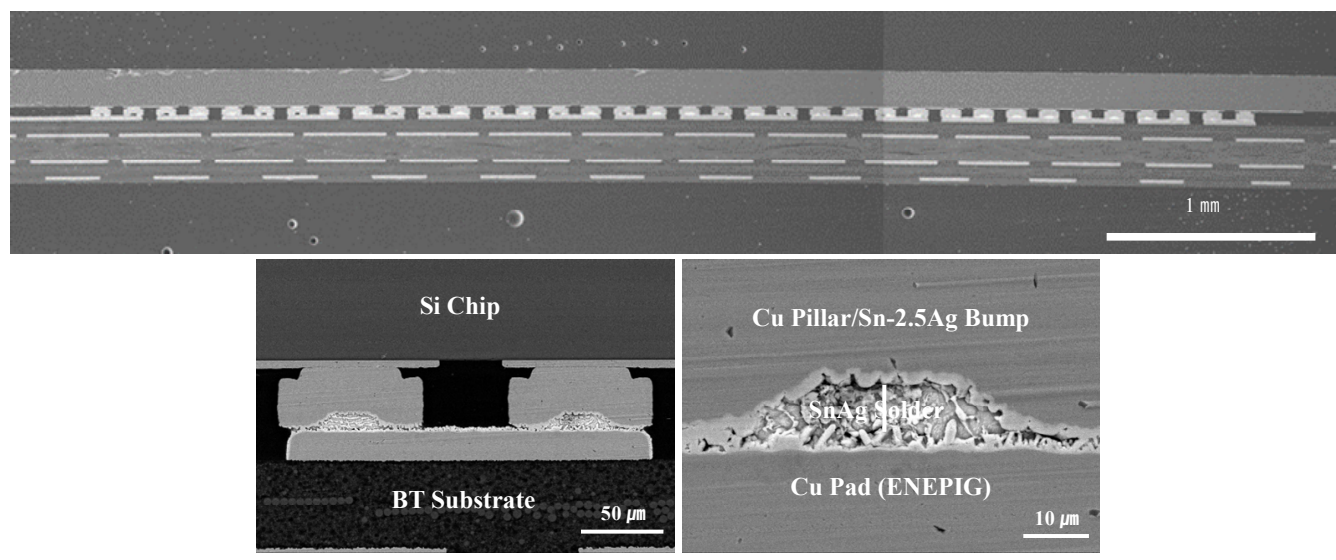

Fig. 11 Cross-sectional SEM micrographs of FC-CSP bonded by profile 3

본 논문은 독자의 이해를 돕기위하여 영문논문을 국문으로 번역하여 게재한 논문입니다. 저자는 본 논문으로 연구업적과 같은 실적에 중복으로 지원받거나 인정받을 수 없음을 알려드립니다. 
(a)

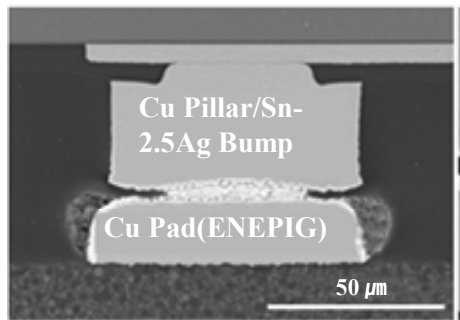

(b)

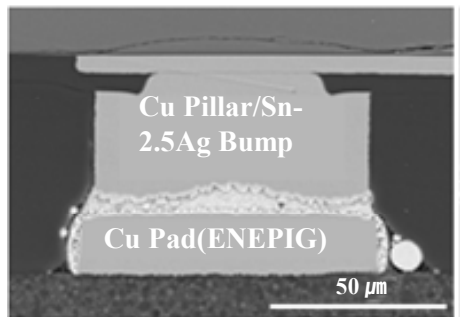

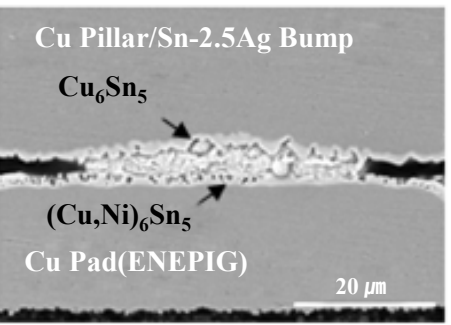

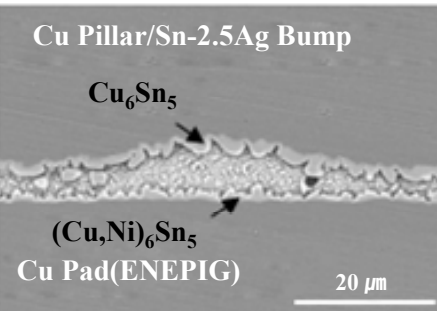

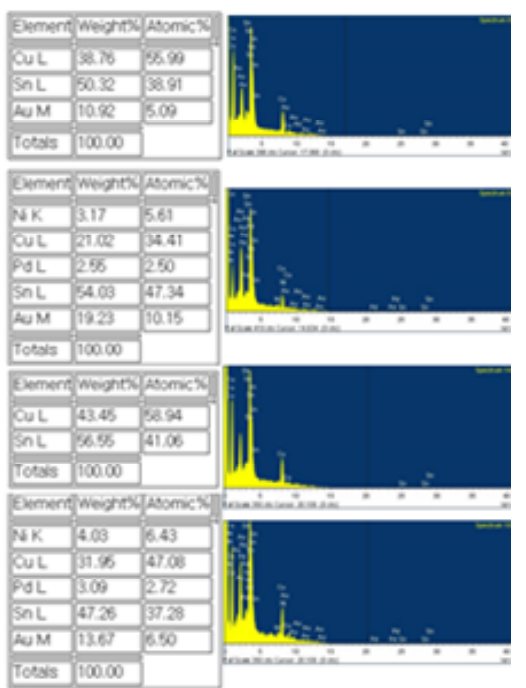

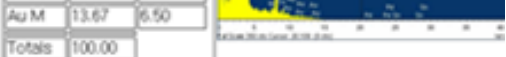

Fig. 12 Cross-sectional SEM micrographs and EDS analysis results of thermal compression bonding profile 3 samples: (a) without solder paste and (b) with solder paste

(a)

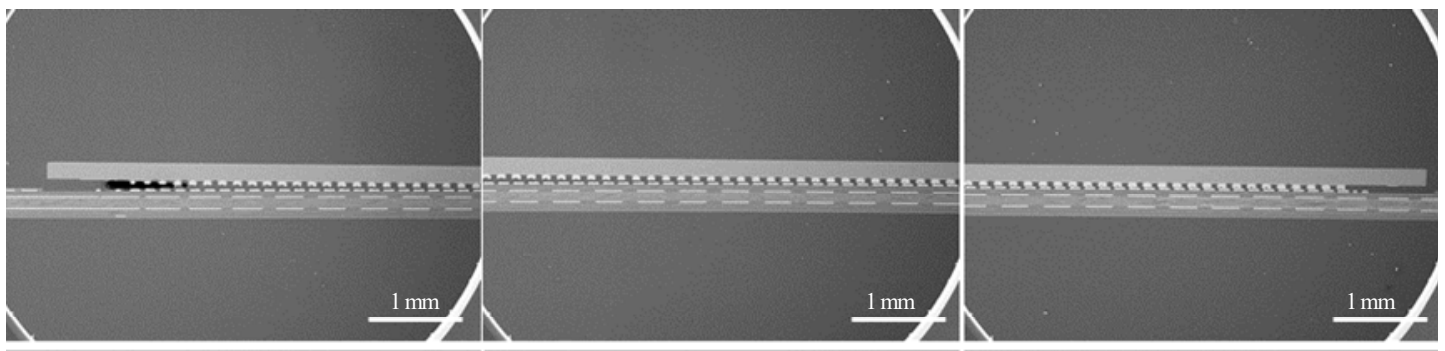

(b)

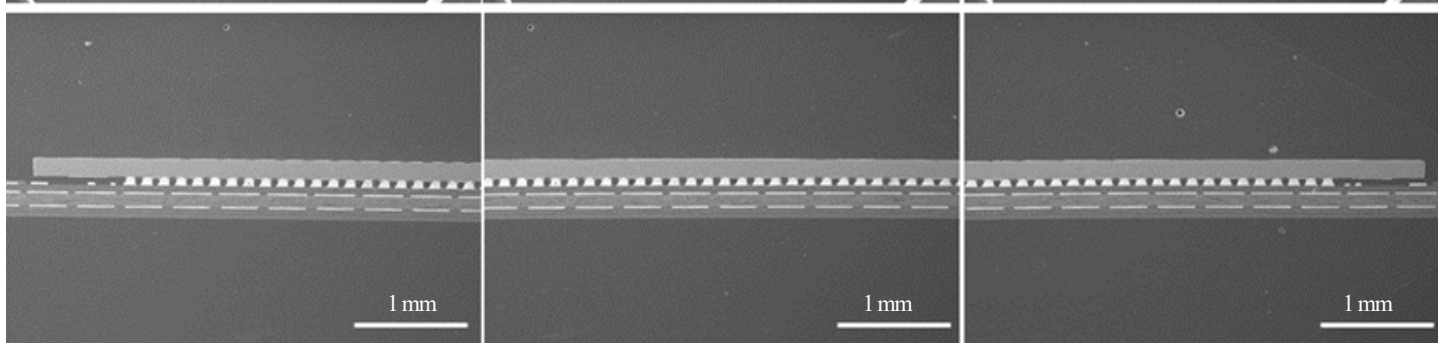

Fig. 13 Cross-sectional SEM micrographs after the vacuum reflow bonding using by bonding

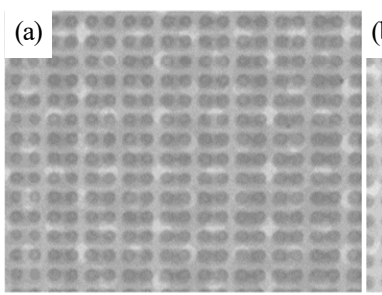

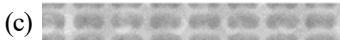

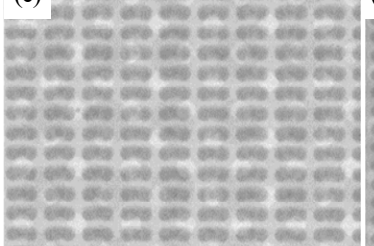

Fig. $14 \mathrm{X}$-ray non-destructive analysis images after the vacuum reflow soldered FC-CSP using by (a) bonding profile 1 , (b) bonding profile 2, (c) bonding profile 3 and (d) bonding profile 4
로 측정되었다.

공정에 따른 솔더의 두께는 $\mathrm{TC}$ 접합부에서 $4.1 \mu \mathrm{m}$, 솔더 페이스트 프린팅을 적용한 $\mathrm{TC}$ 접합부에서 6.5 $\mu \mathrm{m}, \mathrm{VR}$ 접합부에서 $10.3 \mu \mathrm{m}$ 이었고, 전체 접합부 대 비 $\mathrm{IMC}$ 두께비율은 $\mathrm{TC}$ 접합부에서 약 $40 \%$, 솔더 페 이스트 프린팅을 적용한 $\mathrm{TC}$ 접합부에서 약 $32 \%, \mathrm{VR}$ 접합부에서 약 $43 \%$ 로 계산되었다. 선행연구에 따르면 $\mathrm{TC}$ 접합부에서 균열은 피로에 의한 연성파괴로 발생하 여 크리프(creep)에 의한 micro-void를 통해 전파되 고, $\mathrm{IMC}$ 의 균열은 주로 $\mathrm{Cu}_{6} \mathrm{Sn}_{5}$ 혹은 $\mathrm{Cu}_{3} \mathrm{Sn}$ 의 계면 을 따라 취성파괴에 의해 발생한다고 보고된다 ${ }^{10)}$. 또한 접합부에서 솔더의 부피가 커질수록 접합부의 균열 발 생 및 전파를 감소시켜 피로 수명이 향상된다고 보고되 어 있다 ${ }^{11)}$. 따라서 솔더의 부피가 가장 컸던 $\mathrm{VR}$ 접합 


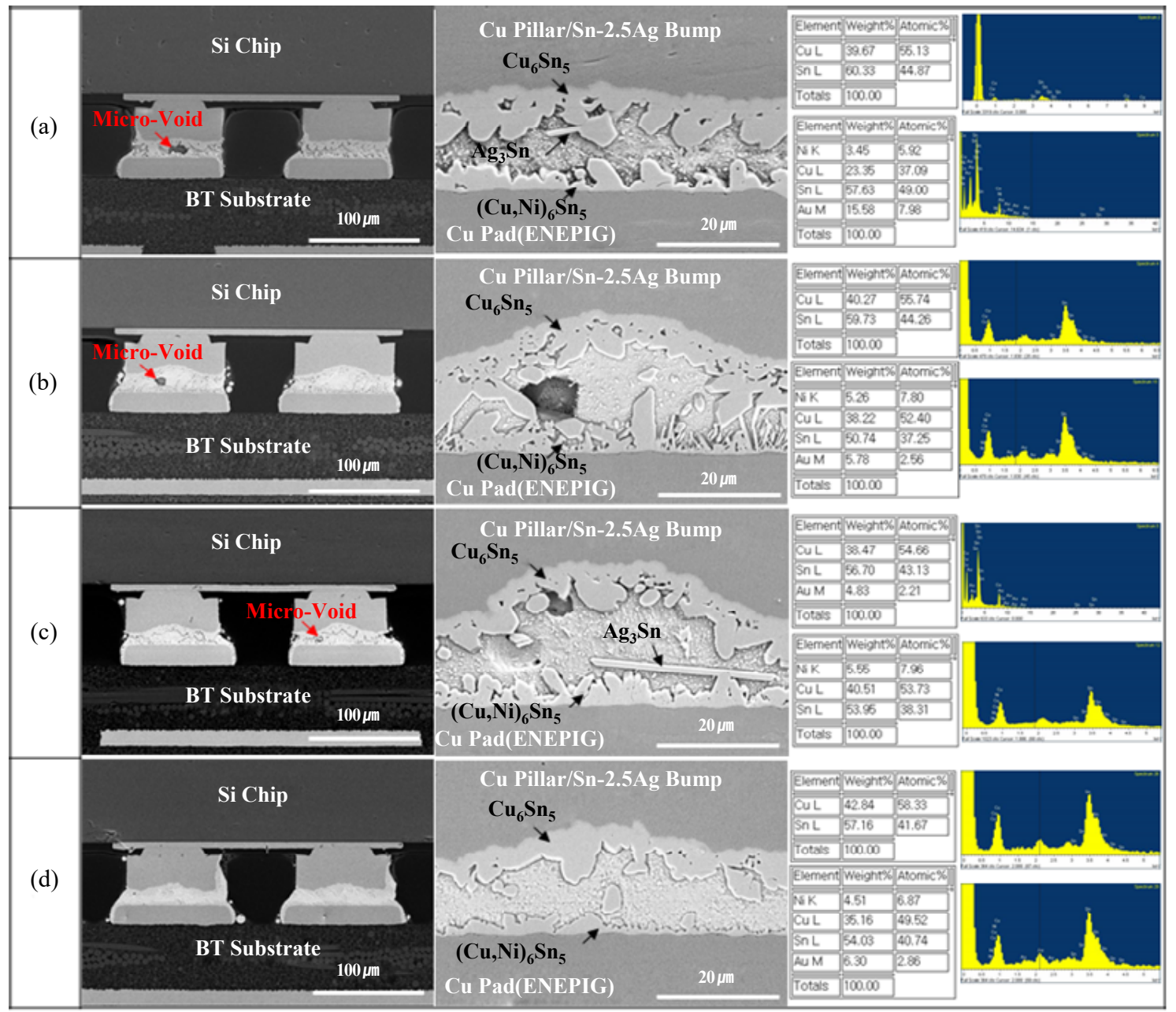

Fig. 15 Cross-sectional SEM micrographs and EDS analysis results after the vacuum reflow soldered FC-CSP using by (a) bonding profile 1, (b) bonding profile 2, (c) bonding profile 3 and (d) bonding profile 4

부와 $\mathrm{IMC}$ 두께의 비율이 가장 낮았던 프린팅 적용 $\mathrm{TC}$ 접합부가 기존 $\mathrm{TC}$ 공정의 접합부보다 신뢰성에 더 유 리할 것으로 생각되었다. 또한, $\mathrm{VR}$ 공정온도를 더 낮 춘다면 더 효과적으로 신뢰성을 향상시킬 수 있을 것으 로 판단되었다.

\section{4. 결 론}

본 연구에서는 $90 \mu \mathrm{m}$ 직경의 $\mathrm{Cu}$ pillar $\mathrm{Sn}-2.5 \mathrm{Ag}$ 범프가 형성된 칩과 ENEPIG 표면처리 된 $\mathrm{BT}$ substrate를 사용하여 $\mathrm{FC}-\mathrm{CSP}$ 의 열압착 접합공정을 최적 화하였다. $\mathrm{TC}$ 접합 및 $\mathrm{VR}$ 접합을 진행했으며, Type 7 $\mathrm{Sn}-3.0 \mathrm{Ag}-0.5 \mathrm{Cu}$ 솔더 페이스트의 프린팅 공정을 적 용하여 3 원계 솔더의 $\mathrm{TC}$ 및 $\mathrm{VR}$ 접합공정을 최적화하 였다.

1) Type 5 및 Type 7 솔더 페이스트, $30 \mu \mathrm{m}$ 및 $50 \mu \mathrm{m}$ 두께와 개구율 $70 \%$ 및 $100 \%$ 의 metal mask를 이용 한 프린팅 공정 최적화 결과 Type 7 솔더 페이스트와
$30 \mu \mathrm{m}$ 두께의 개구율 $100 \%$ metal mask가 가정 적 합한 것을 알 수 있었다.

2) Flip chip-BT substrate 접합공정에 TC 접합, 솔더 페이스트 프린팅 공정을 적용한 $\mathrm{TC}$ 접합 및 $\mathrm{VR}$ 접합공정을 적용하여 접합공정을 최적화하였다. 접합부 상부에서 $\mathrm{Cu}_{6} \mathrm{Sn}_{5} \mathrm{IMC}$ 층이, 하부에서 $\left(\mathrm{Cu}, \mathrm{Ni}_{6}\right)_{6} \mathrm{Sn}_{5}$ $\mathrm{IMC}$ 층이 형성되었다. 솔더 접합부 두께는 각각 $4.1 \mu \mathrm{m}$, $6.5 \mu \mathrm{m}, 10.3 \mu \mathrm{m}$ 였으며, IMC 두께 비율은 약 $40 \%$, $32 \%, 43 \%$ 로 계산되었다.

3) Type 7 솔더 페이스트 프린팅 공정을 적용한 TC 접합 및 $\mathrm{VR}$ 접합공정 결과, 기존 $\mathrm{TC}$ 공정보다 솔더의 부피가 증가하면서 IMC 두께 비율이 낮아지는 효과로 솔더 접합부의 균열 발생 및 전파를 감소시켜 신뢰성에 유리할 것으로 판단되었다.

\section{후 기}

본 연구는 산업통상자원부의 소재부품기술개발사업 
(과제번호: 20011427)의 지원을 받아 수행된 연구결 과입니다.

ORCID: Mi-Song Kim: https://orcid.org/0000-0002-4717-9365 ORCID: Won Sik Hong: http://orcid.org/0000-0001-8398-177X ORCID: Myeongin Kim: https://orcid.org/0000-0002-5151-1404

\section{References}

1. S. H. Ahn, Fine Pitch Surface Mount Technology, J. Korean Weld. Join. Soc. 13(4) (1995) 30-35.

2. S. H. Yoo and C. W. Lee, Through Silicon Via Filling and Fine Pitch Joining Technology for 3D Electronic Package, J. Korean Weld. Join. Soc. 27(3) (2009) 17-22.

3. M. J. Lee, M. Yoo, J. H. Cho, S. K. Lee, J. D. Kim, C. H. Lee, D. B. Kang, C. Zwenger, and R. Lanzone, Study of Interconnection Process for Fine Pitch Flip Chip, Proceedings of Electronic Components and Technology Conference (ECTC), IEEE 60th (2009) 234-239. https://doi.org/10.1109/ECTC.2009.5074092

4. M. S. Kim, M. S. Kang, J. H. Bang, C. W. Lee, M. S. Kim, and S. H. Yoo, Interfacial Reactions of Fine-Pitch $\mathrm{Cu} / \mathrm{Sn}-3.5 \mathrm{Ag}$ Pillar Joints on $\mathrm{Cu} / \mathrm{Zn}$ and $\mathrm{Cu} / \mathrm{Ni}$ Under Bump Metallurgies, J. Alloys Compd. 616 (2014) 394-400. http://dx.doi.org/10.1016/j.jallcom.2014.07.124

5. K. S. Choi, H. Lee, H. C. Bae, and Y. S. Oem, Recent Trends of Flip Chip Bonding Technology, Electron. Telecommun. Trends, 28(5) 100-110.

6. S. J. Kim, W. S. Hong, H. B. Nam, and N. H. Kang, Growth Behavior of Intermetallic Compounds in Various Solder Joints Induced by Electromigration, J. Weld. Join.
39(1) (2021) 89-102.

https://doi.org/10.5781/JWJ.2021.39.1.11

7. J. H. Back, S. H. Yoo, D. G. Han, S. B. Jung, and J. W. Yoon, Effect of Thin ENEPIG Plating Thickness on Interfacial Reaction and Brittle Fracture Rate of Sn3.0Ag-0.5Cu Solder Joints, J. Weld. Join. 36(5) (2018) 52-60. https://doi.org/10.5781/JWJ.2018.36.5.7

8. S. S. Ha, D. G. Kim, J. W. Kim, J. W. Yoon, J. H. Joo, Y. E. Shin, and S. B. Jung, Interfacial Reaction and Joint Reliability of Fine-Pitch Fip-Chip Solder Bump Using Stencil Printing Method, J. Microelectron. Eng. 84 (2007) 2640-2645. https://doi.org/10.1016/j.mee.2007.05.062

9. J. H. Back, S. H. Yoo, D. G. Han, S. B. Jung, and J. W. Yoon, Interfacial Reactions and Mechanical Strength of Sn-3.0Ag-0.5Cu/0.1 $\mu \mathrm{m}-\mathrm{Ni}$ Thin ENEPIG Solder Joints, J. Weld. Join. 35(6) (2017) 51-58. https://doi.org/10.5781/JWJ.2017.35.6.8

10. J. Li, Y. Zhang, H. Zhang, Z. Chen, C. Zhou, and X. Liu, W. Zhu, The Thermal Cycling Reliability of Copper Pillar Solder Bump in Flip Chip Via Thermal Compression Bonding, J. Trans. Microelectron. Reliab. 104 (2020) 1-12. https://doi.org/10.1016/j.microrel.2019.113543

11. K.Y. Au, F. X. Che, J. K. Lin, H. Y. Hsiao, X. Zhang, S. Lim, J. L. Aw, and A. Chow, Thermal Compression Bonding of $30 \mu \mathrm{m}$ Pitch $\mathrm{Cu}$ Pillar Microbump on Organic Substrate with Bare Cu Bondpad, Proceedings of Electronic Components and Technology Conference (ECTC), IEEE 66th (2016) 936-942.

https://doi.org/10.1109/ECTC.2016.127 